\title{
Processing and Characterization of Self-Reducing Briquettes Made of Jarosite and Blast Furnace Sludges
}

\author{
Davide Mombelli ${ }^{1}\left[\right.$ Danilo Luvizotto Gonçalves $^{1} \cdot$ Carlo Mapelli $^{1} \cdot$ Silvia Barella ${ }^{1} \cdot$ Andrea Gruttadauria $^{1}$
}

Received: 19 February 2021 / Accepted: 2 August 2021 / Published online: 13 September 2021

(c) The Author(s) 2021

\begin{abstract}
Jarosite sludge coming from the hydrometallurgical zinc production route is a hazardous material, which is currently neutralized and landfilled by the so-called Jarofix $®$ process. The present study aims to assess the mechanical and metallurgical properties of briquettes made of jarosite powder with blast furnace sludges, acting as a reductant material, to recover the iron oxide in the form of pig iron and produce an inert slag, increasing the recovery of materials considered as wastes nowadays. Starch was used as a binder $(0,5,10 \mathrm{wt} \%)$, and two different briquetting pressure levels were used (20 and $40 \mathrm{MPa})$. The results show that briquetting without a binder is not desirable, as the agglomerating forces provided by pressure only are not sufficient, as the briquettes are very fragile and not handy. The binder addition increased noticeably the briquettes resistance, however, only little distinction between the 5 and $10 \mathrm{wt} \%$ levels were seen. The briquetting pressure, on the other hand, showed a bigger role on the cold mechanical properties of the bound briquettes. The briquettes pressed at $40 \mathrm{MPa}$ reached an average compressive strength higher than $12 \mathrm{MPa}$ and good abrasion and drop resistance were seen, also showing that their production with starch as a binder is feasible. A special remark is done regarding the roasting treatment of the jarosite powder before the briquetting process, as an undesirable compound (thenardite) was formed within some briquettes due to a non-uniform heating of the powder, which hindered the briquettes mechanical properties. Metallurgical properties open the possibility to use such briquettes for iron production in cupola furnaces.
\end{abstract}

\section{Graphical Abstract}

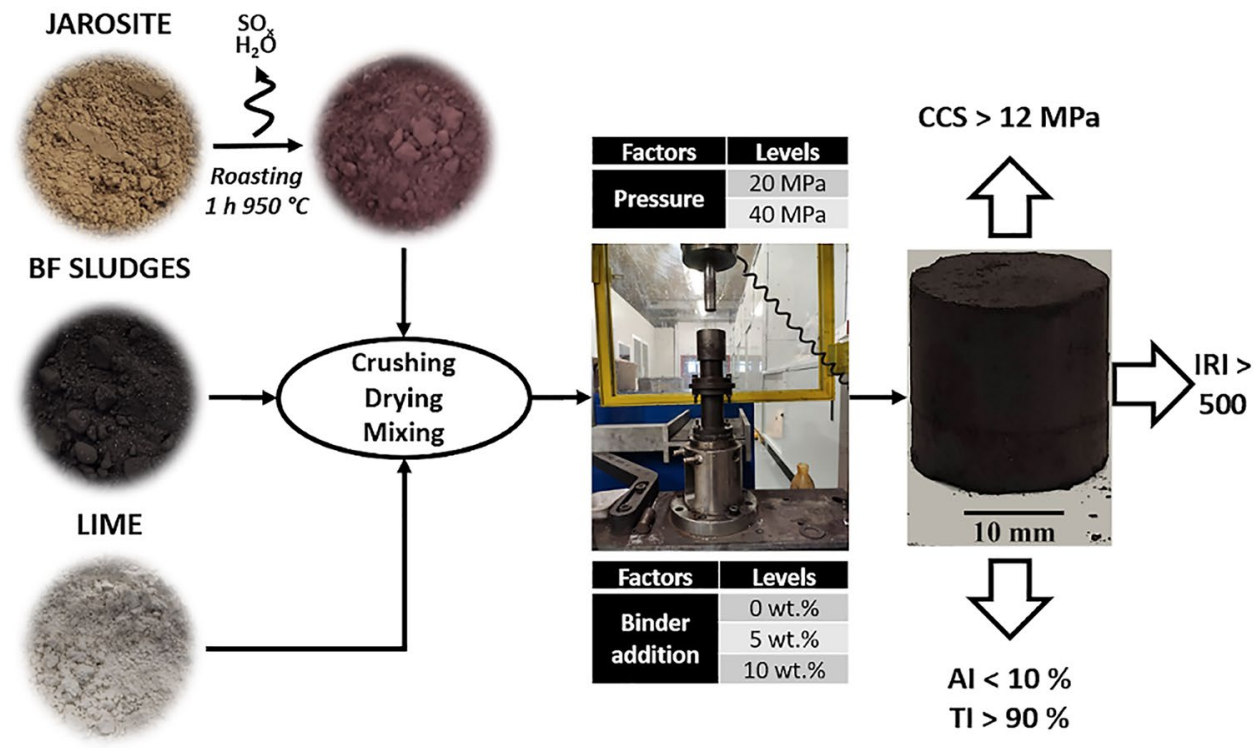

Keywords Jarosite $\cdot$ Blast furnace sludges $\cdot$ Starch $\cdot$ Briquetting $\cdot$ Briquettes mechanical properties

The contributing editor for this article was Veena Sahajwalla

Extended author information available on the last page of the article 


\section{Introduction}

Jarosite is produced as a part of the jarosite process in zinc hydrometallurgy. In particular, the jarosite process allows the precipitation of iron and its following filtering, which leads to an increase of zinc extraction yield. Zinc and iron are present as sphalerite $[(\mathrm{Zn}, \mathrm{Fe}) \mathrm{S}][1,2]$. Therefore, due to the competitive formation of zinc and iron sulfides, an excess of sulfuric acid is used for the leaching process, which leads to hydrolysis and the iron precipitation as hydronium jarosite. Other jarosite compounds can be formed due to the presence of $\mathrm{K}^{+}, \mathrm{Na}^{+}, \mathrm{NH}_{4}{ }^{+}$, and $\mathrm{Pb}$ in the leaching solution, such as natrojarosite $\left[\mathrm{NaFe}_{3}\left(\mathrm{SO}_{4}\right)_{2}(\mathrm{OH})_{6}\right]$, ammoniojarosite $\left[\mathrm{NH}_{4} \mathrm{Fe}_{3}\left(\mathrm{SO}_{4}\right)_{2}(\mathrm{OH})_{6}\right]$, and plumbojarosite $\left[\mathrm{PbFe}_{6}\left(\mathrm{SO}_{4}\right)_{4}(\mathrm{OH})_{12}\right]$. These compounds are considered hazardous, due to the presence of $\mathrm{Cd}, \mathrm{As}, \mathrm{Zn}$ itself, and $\mathrm{Pb}$. The following possible formation of complex groups with the main jarosite elements could lead to soil contamination and acidification $[3,4]$.

Due to the high content of iron $(40 \%-50 \%)$ present in the jarosite, and the possible further presence of zinc, copper, and zinc, several efforts have been taken to recover these elements. Moreover, the recovery of these elements would transform the jarosite from a hazardous material to a nonhazardous one, making its disposal easier from both economic and environmental point of view $[5,6]$.

The Jarofix ${ }^{\circledR}$ process is still one of the best technologies for neutralizing the jarosite leachable residues: the filtered jarosite is initially mixed with lime and then with Portland cement. This mix reacts with itself during time, producing inert elements, such as ferric oxyhydroxide $\left[\mathrm{Fe}_{2} \mathrm{O}_{3} \cdot 3 \mathrm{H}_{2} \mathrm{O}\right.$, $\left.\mathrm{Ca}_{6} \mathrm{Fe}_{2}\left(\mathrm{SO}_{4}\right) 3(\mathrm{OH})_{12} \cdot \mathrm{nH}_{2} \mathrm{O}\right]$ and sodium sulfate, that further reacts generating gypsum. Moreover, the Portland cement reacts to form $\mathrm{Ca}-\mathrm{Al}-\mathrm{Fe}$ silicate hydrate phases and $\mathrm{Ca}-\mathrm{Al}-\mathrm{Fe}$ oxide. These new products are much more stable and inert than the initial jarosite, resisting through years of physical and chemical testing, reducing the longterm environmental issues, such as water and soil contamination, allowing the disposal of the jarosite wastes into inert material landfills [7].

Thanks to the promising high-strength cement of the jarosite and Portland cement mix, it could be possible to be applied for the production of roads and airfield runaways [8]. Moreover, the use of jarosite in the Portland cement in alternative to natural gypsum would lead to a decrease in the economic cost of the overall cement production [9].

The annual production of jarosite wastes are about 6 million tons per year [10] and even if the Jarofix ${ }^{\circledR}$ and the jarosite addition to cement are two possible solution, the recovery of valuable elements like iron is not exploited by these methods. Furthermore, the Jarofix ${ }^{\circledR}$ process requires several hectares of landfilling spaces in order to deposit the processed material, which has limited working life [11, 12]. Therefore, the development of new techniques for the recovery of valuable materials from the jarosite is a challenging research field.

Zhu et al. studied a pyrometallurgical route for separation of heavy metals from jarosite residues, consisting mainly of sodium jarosite, with $28 \mathrm{wt} \%$ iron, $12.78 \mathrm{wt} \%$ sulfur, and $3.76 \mathrm{wt} \%$ zinc, and traces of $\mathrm{Pb}$ and $\mathrm{Cd}$. Through a two-step heating process, more than $93 \%$ of iron was transformed in pig iron, whereas sulfur was reduced up to $0.05 \mathrm{wt} \%$ [13]. Similarly, Mombelli et al. also studied the jarosite sludges reduction, using an arc-transferred plasma reactor. The main jarosite compound was the natrojarosite and plumbojarosite. The pig iron obtained after the heat treatment showed high amounts of S, P, and $\mathrm{Cu}(>1 \mathrm{wt} \%)$, with a structure close to a white cast iron. Moreover, the slag formed at the end of the process consists of $\mathrm{SiO}_{2}-\mathrm{Al}_{2} \mathrm{O}_{3}-\mathrm{Fe}_{2} \mathrm{O}_{3}$ glass, and does not show any leaching behavior, making it suitable for disposal at inert waste landfills or to be used in civil construction. Note that still, the dust coming from the arc transferred plasma furnace can be recirculated to the Roast-Leach-Electrowin (RLE) process [14].

Although coke can be used for the jarosite wastes reduction so as to obtain pig iron, several problems are associated to its production: the high amount of green-house gas emissions, the negative health impact to the population near the production plants, and the high cost associated to the coal mining are just some of them [15-18]. Alternative reductant agents, such as $\mathrm{H}_{2}$ and syngas, have been proposed in order to reduce the coke consumption; however, their high cost hinders their use [19]. One possible solution is the use of blast furnace wastes with high amounts of carbon content, such as the blast furnace sludges, which have already provided satisfactory results regarding the reduction of bauxite tailings red mud [20], BOF dust [21], and low-grade iron ores [22].

The reduction of jarosite to produce pig iron by the use of blast furnace sludges has been studied by Mombelli et al. [23]. The carbon contained in the sludge allowed the reduction of the iron oxide contained both in the sludge and jarosite at a temperature of $1500{ }^{\circ} \mathrm{C}$. In particular, the best $\mathrm{C} / \mathrm{Fe}_{2} \mathrm{O}_{3}$ ratio found was 0.261 and the main advantages of the process were the formation of a vitrified structure of the slag, making it stable against toxic element leaching, and a metal/charged material ratio higher than 30\%, confirming the applicability of the process from both an environmental and economical point of view [23].

However, both the jarosite and the blast furnace sludges come in the form of fine powder that can be easily carried away or lost, so the material handling can be cumbersome. Therefore, they may require agglomeration techniques, such as briquetting, to achieve both the handling and safety 
requirements. Briquetting could be explored to allow easier handling of these materials, together with binder to better increase the physical properties of the product. Encouraging results have shown the applicability of briquettes, as alternative or additional charging material, in both Midrex ${ }^{\circledR}$ process and cupola furnaces [24-26].

The main aim of the presented work is to produce and characterize novel jarosite/blast furnace sludges self-reducing briquettes with sufficient cold strength and metallurgical properties to be used in a thermal reactor, such as a Midrex ${ }^{\circledR}$ or a cupola furnace, without material loss during handling. The binder chosen for the briquetting is corn starch. Starch is a polymer classified as an organic binder, and it can be used as dry matter or as a gel. This leads to a disruption of the intermolecular bonds, generating hydrogen-bonding sites, increasing the number of water molecules that can be attached, increasing solubility in cold water [27]. Starch is used in the briquetting of charcoal [27-29] as well as it can be used as a substitute of bentonite in the pelletizing of steelmaking by-products (blast furnace sludges, BOF dusts, and mill scale) [30-33].

\section{Materials and Methods}

\section{Raw Materials}

The jarosite used in the present study, previously characterized by Mombelli et al. [14], is a greenish powder (mean diameter from $2 \mu \mathrm{m}$ to $5 \mu \mathrm{m}$ ) mainly composed of natrojarosite and plumbojarosite. The chemical compositions of materials used are reported in Table 1.

The powder was roasted in a muffle furnace at $950{ }^{\circ} \mathrm{C}$ for $60 \mathrm{~min}$ to remove hydroxide species and impurities. Most of the jarosite species decomposed into hematite, increasing the iron oxides concentration from 33 to $55 \mathrm{wt} \%$, and reducing considerably the S content from 8.86 to 2.55 wt $\%$, decomposed in the form of $\mathrm{SO}_{\mathrm{x}}$ gas phases. After roasting, the powder appearance turned from greenish (Fig. 1a) to rusty (Fig. 1b); the phase modifications were identified through XRD analysis and the results are shown in Fig. 2. A more detailed description of the roasting process is discussed by Mombelli et al. [14]. After roasting, the jarosite powder was ground in a Retsch Planetary Ball Mill PM 400 machine for
Table 1 Blast furnace sludges [23] and jarosite ED-XRF chemical composition before and after roasting [14] (\% by weight)

\begin{tabular}{llllllllllll}
\hline Major element & $\mathrm{C}$ & $\mathrm{Fe}_{2} \mathrm{O}_{3}$ & $\mathrm{~S}$ & $\mathrm{ZnO}$ & $\mathrm{SiO}_{2}$ & $\mathrm{PbO}$ & $\mathrm{Na}_{2} \mathrm{O}$ & $\mathrm{CaO}$ & $\mathrm{As}_{2} \mathrm{O}_{5}$ & $\mathrm{BaO}$ & $\mathrm{Al}_{2} \mathrm{O}_{3}$ \\
\hline Jarosite & - & 33.32 & 8.86 & 7.28 & 6.44 & 5.62 & 2.80 & 1.51 & 1.08 & 0.78 & 0.73 \\
Roasted jarosite & - & 55.12 & 2.55 & 12.40 & 11.77 & 5.29 & 3.01 & 1.30 & 1.04 & 0.84 & 0.55 \\
Blast furnace sludges & 49.80 & 30.29 & 0.64 & 2.08 & 8.09 & 2.32 & 1.13 & 3.60 & - & - & 2.62 \\
Lime & 0.06 & - & 0.06 & - & - & - & - & 96.78 & - & - & - \\
JBFS mix & 12.62 & 48.30 & 2.04 & 9.64 & 10.81 & 3.97 & 2.51 & 5.45 & 1.08 & 0.63 & 1.08 \\
\hline Minor element & $\mathrm{MnO}$ & $\mathrm{CuO}$ & $\mathrm{MgO}$ & $\mathrm{K}_{2} \mathrm{O}$ & $\mathrm{TiO}_{2}$ & $\mathrm{Sb}_{2} \mathrm{O}_{5}$ & $\mathrm{Cd}$ & $\mathrm{SnO}$ & $\mathrm{P}_{2} \mathrm{O}_{5}$ & $\mathrm{Other}$ & L.O.I \\
\hline Jarosite & 0.49 & 0.39 & 0.17 & 0.17 & 0.10 & 0.08 & 0.07 & 0.07 & 0.06 & 0.20 & 29.80 \\
Roasted jarosite & 0.63 & 0.46 & 0.48 & 0.19 & 0.11 & 0.09 & 0.07 & 0.08 & 0.06 & 0.25 & 3.72 \\
Blast furnace sludges & 0.12 & - & 0.74 & 0.91 & 0.13 & - & - & - & 0.14 & 0.11 & - \\
Lime & - & - & 0.46 & & - & - & - & - & - & 2.01 & 1.15 \\
JBFS mix & 0.49 & 0.34 & 0.56 & 0.16 & 0.11 & 0.08 & 0.05 & 0.07 & 0.05 & 1.4 & - \\
\hline
\end{tabular}
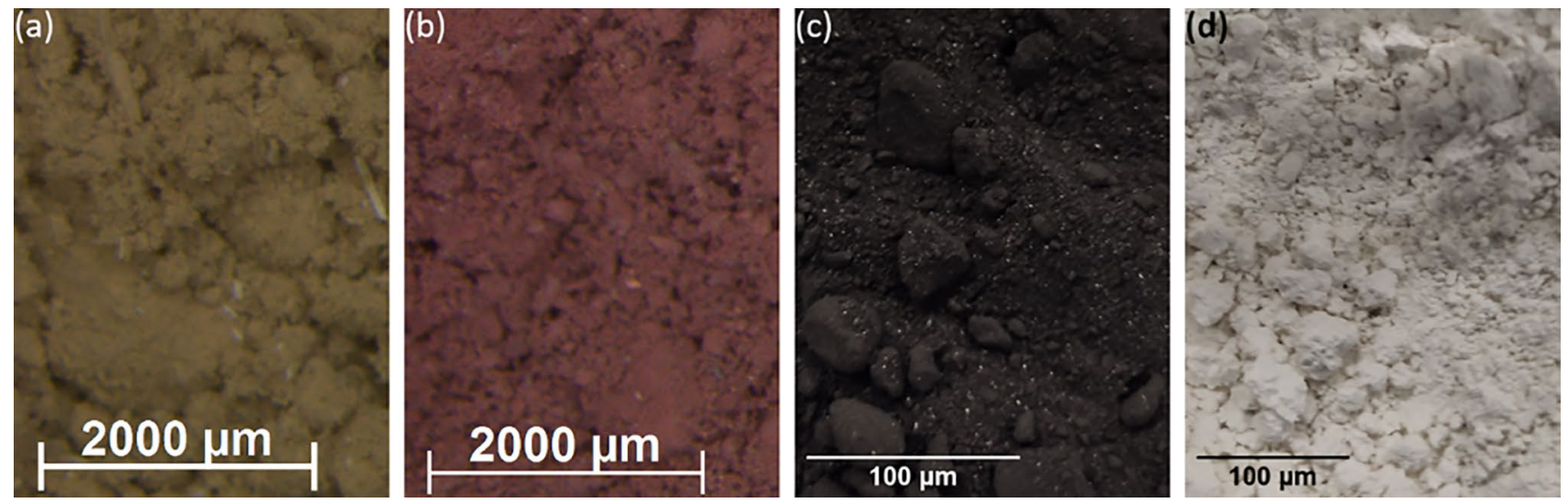

Fig. 1 Jarosite before (a) and after (b) roasting; blast furnace sludges (c) and lime (d) used for the manufacturing of the briquettes 
$15 \mathrm{~min}$ at $300 \mathrm{rpm}$ using zirconia balls. Due to the coarsening and hardening of the powder after roasting, the powder was sieved though a $125 \mu \mathrm{m}$ sieve in order to obtain a more homogeneous dimensional distribution. The sieved powder was then dried overnight at $105{ }^{\circ} \mathrm{C}$ in a muffle furnace.

The blast furnace sludges composition is given in Table 1, also in this case they were previously characterized by Mombelli et al. [23]. The sludges appeared as fine dark particles (Fig. 1c), with very low mechanical resistance agglomerates, easily crushable without the need of any dedicated machinery. As for the jarosite powders, the blast furnace sludges powder was sieved through a $125 \mu \mathrm{m}$ sieve and dried at $105{ }^{\circ} \mathrm{C}$ overnight in a muffle furnace. The results of the XRD analysis (Fig. 2c) highlighted the presence of mainly hematite and magnetite with residual amount of unburnt coke (amorphous halo at $25^{\circ} 2 \theta$ ) that partially graphitized after the exposure at high temperature. Traces of reacted non-ferrous compounds (carnegieite and diopside) were also observed, probably originated from mineral reactions of gangue and limestone [34-36].

The jarosite and blast furnace sludges were then mixed with a weight proportion of $2.75: 1$, in order to achieve a $\mathrm{C} / \mathrm{Fe}_{2} \mathrm{O}_{3}$ mass proportion of 0.261 , which was the optimal ratio for the reduction of the iron contained in the jarosite found by Mombelli et al. [23]. In order to improve the slag basicity index, $5 \mathrm{wt} \%$ of lime over the total jarosite mass used was added (Table 1). Before mixing, lime was dried at $550{ }^{\circ} \mathrm{C}$ for three hours to decompose the eventual hydroxide. The chemical composition of the final mix (labeled JBFS) is shown in Table 1.

The binder chosen for the briquetting is corn starch, the XRD pattern of the starch (Fig. 2d) is in accordance with the literature [37-39]. The corn starch was gelatinized by heating at $80{ }^{\circ} \mathrm{C}$ (starch to water proportion 1:6) for $20 \mathrm{~min}$ so as to increase its viscosity and obtain higher binding properties. Two different corn starch-JBFS mixes were prepared and differentiated in accordance with the amount of starch added to the JBFS dry basis: 5 and $10 \mathrm{wt} \%$, respectively. Furthermore, some of the JBFS were not mixed, and used as a control batch to highlight the starch binding effects for the briquettes production. The resulting mix of JBFS and starch is labeled SJBFS.

\section{Briquetting}

Briquetting of the JBFS and the SJBFS mixes were performed by an Instron uniaxial tensile test machine upgraded with a self-designed briquetting machine (Fig. 3b). The briquetting machine (Fig. 3a) is composed of a funnel (internal diameter of $20 \mathrm{~mm}$ ) suitable for housing the powder and threaded to a cylinder. A spring for chrome-vanadium molds supports an ejector that is able to move downwards during the briquetting process. When the machine is activated, a plunger, powered by the machine actuator, starts to press the powder inside the funnel. Once the pressure required for the spring deformation is achieved, the ejector begins to descend and the powder is pushed against the actuator plunger, the pressure is then increased until the chosen value is achieved. Then the pressure is gradually removed and the spring moves the ejector upwards together with the briquette; finally, the funnel is unthreaded, and the briquette is manually removed.

More than 40 briquettes were produced following the described briquetting process with a target height of $20 \mathrm{~mm}$. About $15 \mathrm{~g}$ of JBFS mix was needed in order to obtain the target height; on the other hand, the mass needed varied for the SJBFS mixes based on the binder wt $\%$. Two different briquetting pressure levels (20 MPa and $40 \mathrm{MPa}$ ) were used with a compressing speed of $20 \mathrm{~mm} / \mathrm{min}$. A dwell time of $120 \mathrm{~s}$ was adopted to promote the entrapped gases release and increase the briquette physical properties. The resulting briquettes were then left to dry in ambient temperature until the briquette moisture content did not change over time. In order to provide an internal traceability, the briquettes were labeled according to the pressure and binder amount used, as shown in Table 2.

\section{Physical Characterization}

As the briquettes were ready for the mechanical tests, they were submitted first to dimensional analysis to estimate how the bulk density changes according to the different factor levels. The statistical software used for the ANOVA was Minitab®.

The briquettes were then submitted to three mechanical tests to assess the mechanical properties of the produced briquettes. Three briquettes of each B (5 wt $\%$ starch) and C (10 wt\% starch) levels were sent to compression test, two of C level to the drop test while six of the B level to the drop test, two of the C level and three of B level to the abrasion test, and one of each level to the decrepitation test. Table 3 summarizes test type and total specimens number. Metallurgical properties, namely low-temperature disintegration, swelling, and reducibility were performed on the briquettes showing the best cold strength, namely $\mathrm{B}+$ combination. Two samples were used for each tests.

After each test, a specimen is submitted to X-Ray Diffraction to assess the elements inside the briquettes, and in some cases, a scanning electron microscope (FE-SEM Zeiss SIGMA 500, Oberkochen, Germania) equipped with EDS probe (Oxford Xmax, Abingdon-on-Thames, UK) is used to better understand the compounds formed within the briquettes.

X-ray diffraction was performed by means of a Rigaku Smartlab SE (Tokyo, Japan) diffractometer equipped with XRF suppression 0D/1D detector (D/Tex 250). Manually 
Fig. 2 XRD pattern of $\mathbf{a}$ jarosite, $\mathbf{b}$ roasted jarosite; $\mathbf{c}$ blast furnace sludges and $\mathbf{d}$ corn starch used for manufacturing the briquettes
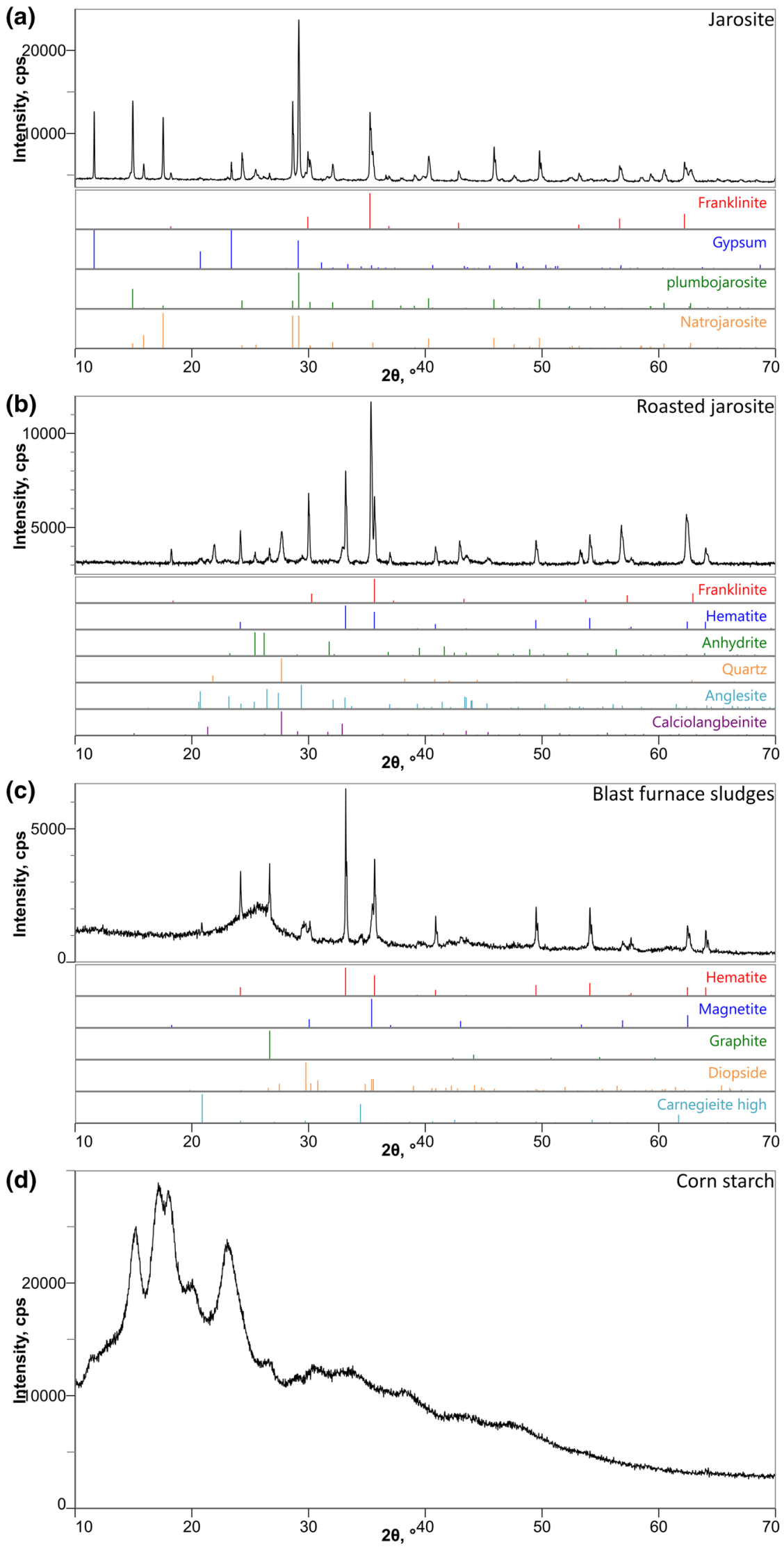

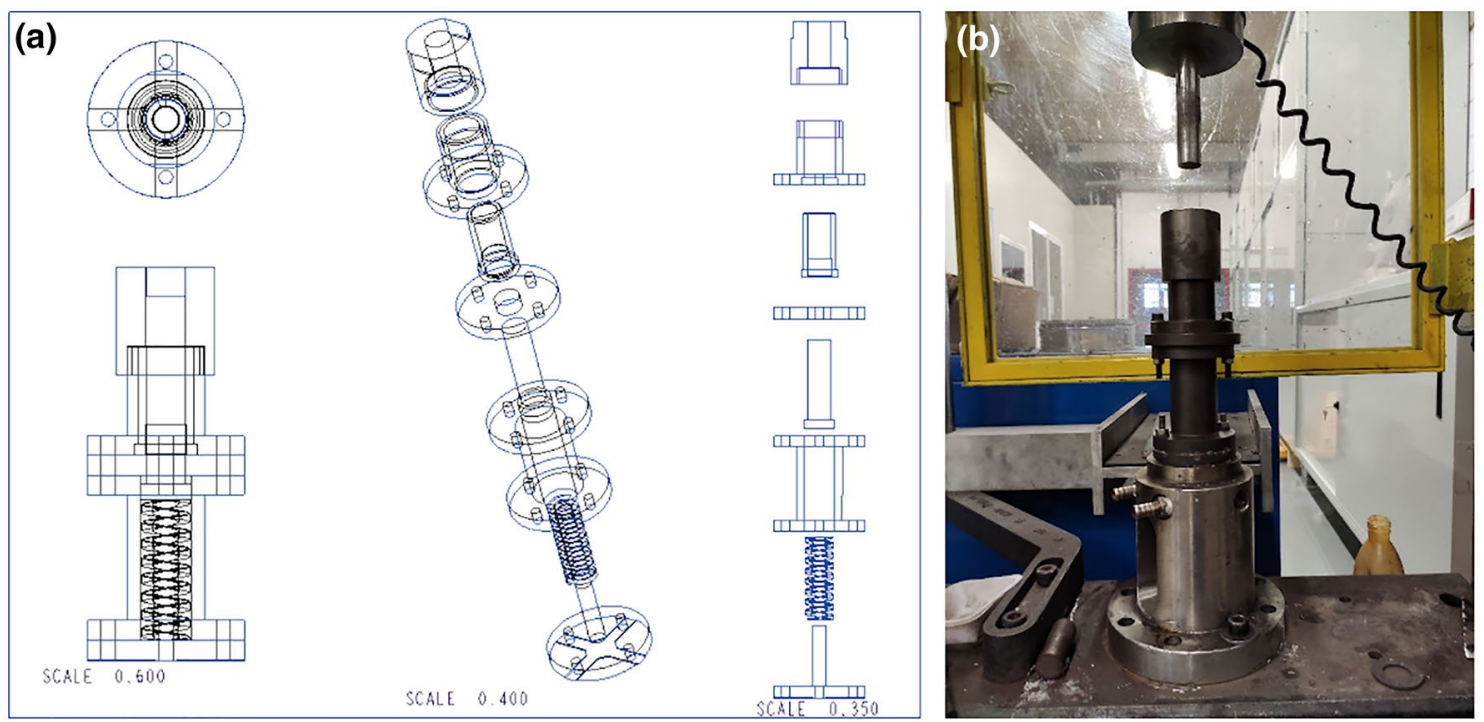

Fig. 3 Self-designed briquetting machine components assembled (a); uniaxial tensile machine upgraded with briquetting machine (b)

Table 2 Summary of the levels and factors used in the briquetting process

\begin{tabular}{lll}
\hline Factors & Levels & Coding \\
\hline Pressure & $20 \mathrm{MPa}$ & - \\
& $40 \mathrm{MPa}$ & + \\
Binder addition & $0 \mathrm{wt} \%$ & $\mathrm{~A}$ \\
& $5 \mathrm{wt} \%$ & $\mathrm{~B}$ \\
& $10 \mathrm{wt} \%$ & $\mathrm{C}$ \\
\hline
\end{tabular}

Table 3 Summary of the total specimens number for each physical test

\begin{tabular}{lll}
\hline Test & $\begin{array}{l}\text { Briquettes } \\
\text { analyzed }\end{array}$ & $\begin{array}{l}\text { Total } \\
\text { specimens } \\
\text { number }\end{array}$ \\
\hline Cold compression test & A & 1 \\
& B & 7 \\
Tumbler and abrasion test & C & 6 \\
Drop test & B & 6 \\
Decrepitation test & C & 4 \\
\multirow{2}{*}{ Metallurgical properties } & B & 6 \\
\end{tabular}

homogenized powders through an agate mortar were scanned from 5 to $90^{\circ} 2 \theta$ at $5^{\circ} / \mathrm{min}$ and excited by a copper tube $(\mathrm{Cu}-$ K $\alpha$ radiation: $\lambda=1.54 \AA$ ). Samples were spin at $120 \mathrm{rpm}$.

\section{Cold Compression Test}

The Compressive Strength of the briquettes were performed inspired by the BS ISO 4700:2015, used for assessing pellets strength, as there are currently no standards for testing steelmaking briquettes. The briquettes were loaded between 2 flat plates, and a pre-load of $30 \mathrm{~N}$ was placed before the test. The test then started at a constant velocity of $15 \mathrm{~mm} / \mathrm{min}$ between the plates, and it was finished when the load falls by $50 \%$ from the recorded maximum value, or when the gap between the plates was reduced by more than $50 \%$ of the briquette diameter, which in the present case is $10 \mathrm{~mm}$.

\section{Tumbler and Abrasion Test}

The abrasion test was done with a tumbler of diameter $180 \mathrm{~mm}$ and length $285 \mathrm{~mm}$ with two L-shaped lifters of $50 \mathrm{~mm}$ flat $\times 50 \mathrm{~mm}$ height employed, with the tumbler rotating at $50 \mathrm{rpm}$. Abrasion and tumbler indexes were calculated according to the BS EN 3271-2015 standard, as reported in Eq. 1 and 2

$\mathrm{TI}=\frac{m_{1}}{m_{0}} \times 100$

$\mathrm{AI}=\frac{m_{0}-\left(m_{1}+m_{2}\right)}{m_{0}} \times 100$,

where $m_{0}$ is the mass of the test portion as weighed out and placed in the tumble drum; $m_{l}$ is the mass, of $+6.70 \mathrm{~mm}$ fraction of the tumbled test portion; $m_{2}$ is the mass of $-6.70 \mathrm{~mm}+500 \mu \mathrm{m}$ fraction of the tumbled test portion. 
The briquettes were put together in pairs, and after 200, 400, and 700 rotations they were sieved and weighed, to assess the $\mathrm{TI}$ and $\mathrm{AI}$ indexes for the respective rotations. Since the equipment and the procedure are not standardized, a comparison with commercial ferroalloys was performed.

\section{Drop Test}

The drop test was done inspired by ASTM D440-07:2019. The apparatus used consisted of an iron vessel in the bottom part to collect the material after the drop and a tube attached to it, with $1.63 \mathrm{~m}$ high, to serve as a guide as the briquette falls inside the vessel. The briquette was dropped ten times, and at least two briquettes should be tested to provide satisfactory results. The material collected after the drops was sieved, and the fraction inside each sieve was weighted and calculated in a percentual basis according to the initial briquette mass. The average opening sizes of the sieves were $6.7 \mathrm{~mm}, 5.6 \mathrm{~mm}, 4 \mathrm{~mm}, 2 \mathrm{~mm}, 1 \mathrm{~mm}, 0.5 \mathrm{~mm}$, and $0.125 \mathrm{~mm}$ and they were normalized according to the biggest (being $6.7 \mathrm{~mm}$ equal to $1,5.6 / 6.7 \mathrm{~mm}$ equal to 0.836 , and so on) for the size stability calculation. The weight percentage of the material collected after the drops are multiplied by the normalizing factor of each sieve average aperture it is collected, generating the size stability value ' $s$,' as the briquettes in the present study have the same diameters (single size).

Also, another parameter used was the impact resistance index calculation, used in some studies [40,41], which consists into dividing the number of drops of each briquette level by the number of pieces it has split apart. The IRI calculation is as shown in Eq. 3:

IRI $=100 \times \frac{\text { Average number of drops }}{\text { Average number of pieces }}$

Another value calculated was the adjusted impact resistance index, which also considers the powder detached during the drop test. For each briquette dropped, the mass of powder retained in each sieve (Mi) below $4 \mathrm{~mm}$ was multiplied by a factor depending on which sieve aperture $(\mathrm{Si})$ it passed, and then everything is summed up to generate an Adjusting Mass factor (Eq. 4). Then the adjusting factor (Eq. 5) is calculated by subtracting 1 from the ratio between the adjusted mass factor and final mass collected at the end of the test. If the adjusting factor is negative, it is considered zero. Then the adjusted impact resistance index is calculated by multiplying the IRI by the adjusting factor, according to Eq. 6. This adjusted index highlights how coarse the powder lost during the drop test is, meaning that an AIRI much lower than IRI represents big losses by fine powder detachment, and the finer the powder detached, the lower the AIRI would be.
Adjusting mass factor $=\sum \frac{4}{\mathrm{Si}} * \mathrm{Mi}$

Adjusting factor $=1-\frac{\text { adjusting mass factor }}{\text { final mass }}$

AIRI $=100 * \frac{\text { average number of drops }}{\text { average number of pieces }} *$ adjusting factor

\section{Decrepitation Test and Metallurgical Performances}

The decrepitation index was evaluated according to BS ISO 8371:2015 standard, by thermal treating the dried briquettes at $700{ }^{\circ} \mathrm{C}$ for $30 \mathrm{~min}$ in air. The briquettes were put in a hot oven preventively stabilized at the test temperature for $1 \mathrm{~h}$. After the test, the briquettes were left to cool down and soon sieved at $6.7-4-2-0.5 \mathrm{~mm}$ sieves (sieve series according to ISO 3310). An electromagnetic sieve shaker IRIS FTS-0200 (Filtra Vibracion, Barcelona, Spain) was used at minimum power. Decrepitation index is defined as is shown in Eq. 7

$\mathrm{DI}_{6.7}=100 \times \frac{m_{2}}{m_{1}}$,

where $m_{l}$ is the mass of the test portion after thermal treatment, $m_{2}$ is the mass of the undersize fraction passing the $6.70 \mathrm{~mm}$ sieve.

Metallurgical performances were evaluated through the definition of low-temperature reduction-disintegration index, free-swelling index, and reducibility inspired by BS ISO 4696-2:2015, BS ISO 4698:2007, and BS ISO 4695:2015, respectively. Self-reducing capability was also evaluated by heat treating the briquettes at 1000 and $1200{ }^{\circ} \mathrm{C}$ under fluxed argon atmosphere for $15 \mathrm{~min}$. Mass loss and mineralogical composition were evaluated after the treated briquettes were cooled down.

\section{Results and Discussion}

\section{Briquetting Procedure Evaluation}

\section{Briquettes Without Starch (JBFS)}

The briquetting machine upgraded on the Instron showed a good replicability and versatility regarding the production of JBFS and SJBFS. All the briquettes produced had a diameter of $20 \mathrm{~mm}$ and showed satisfactory mechanical integrity at glance. 
However, all the A coded briquettes (JBFS) showed difficulties during its production and handling. Careful handling of them was needed, as they seemed very fragile. Since they have no binder, the agglomeration forces present are not enough to allow a reliable production, given that two main effects were observed: first, the A+ briquettes cracked (Fig. 4) as they left the machine, showing a low success rate in the briquetting, nearly $50 \%$. This phenomenon happens due to the high pressures involving the process, which is responsible for high pressure gradients in the briquette external diameter [42] that are not withstand by the agglomeration forces of the briquette.

The other undesirable effect seen was the swelling and the collapse of the briquettes (both A+ and A-) (Fig. 5) after the exposure to the ambient air for a couple of days. The possible swelling can be due to the lime hydration by air, to form calcium hydroxide, or/and by the thenardite-mirabilite transformation happening inside the briquettes according to the change of relative air humidity.

As most of the A briquettes collapsed, their production seemed not viable, so a binder is needed for the correct processing and handling of such briquettes. One A + briquette, which did not suffer from the swelling damaging effects, was sent to the compression test and resulted with not enough resistance.

The briquetting pressures evolution against displacement of A+and A- briquettes (Fig. 6) have almost the same behavior up to a value of $20 \mathrm{MPa}$, with no mechanical forces applied to the powder in the upper cylinder up to approximately $12 \mathrm{~mm}$ of piston displacement. Then, the powder starts to get pressed, forcing the machine spring downwards, resulting in an almost constant slight pressure increase from 12 to $48 \mathrm{~mm}$ of the piston displacement (segment A). When the spring is fully deformed (B point), the pressure starts to sharply increase (segment $\mathrm{C}$ ). The $\mathrm{A}-$ briquettes reach the $20 \mathrm{MPa}$, and the dwell time starts, while the A+briquettes have further pressing, where a smooth inflection in

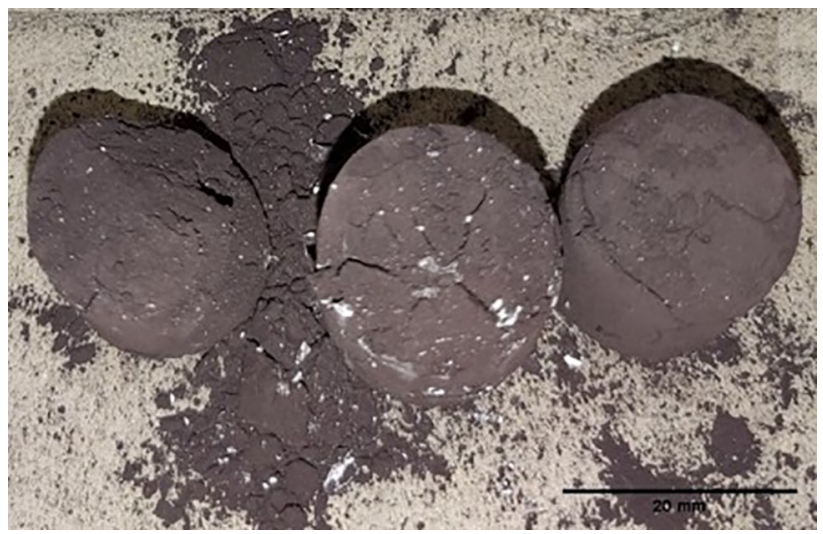

Fig. 5 Damaged briquettes due to swelling, happening on both $\mathrm{A}+$ and $\mathrm{A}-$ briquettes

the pressure is seen (segment $\mathrm{D}$ ). This may be due to the gas entrapment and release through the briquettes powder and to the plastic deformation or fragmentation of the particles [43] for a better accommodation of them.

\section{Briquettes with Starch (SJBFS)}

The $\mathrm{B}$ and $\mathrm{C}$ coded briquettes (Fig. 7), on the other hand, showed no difficulties in their production, as the binder addition seemed to give enough strength to the briquettes; therefore, no cracking issues in their retrieval from the machine and swelling during their drying period were seen.

As the moisture content in the binder was significant, the total volume of the mass inserted in the upper cylinder was higher than with A coded briquettes, and when the pressure during the production increased, water started to pour out from the machine gaps leading to some variation in the briquettes height with respect to the A coded ones. Figure 8 shows the briquetting pressures developed during the briquettes production. Like the unbound briquettes, the
Fig. 4 A-coded briquettes with no apparent issues during their production initially (a); A+ coded briquettes, with a low success rate in its production (b)
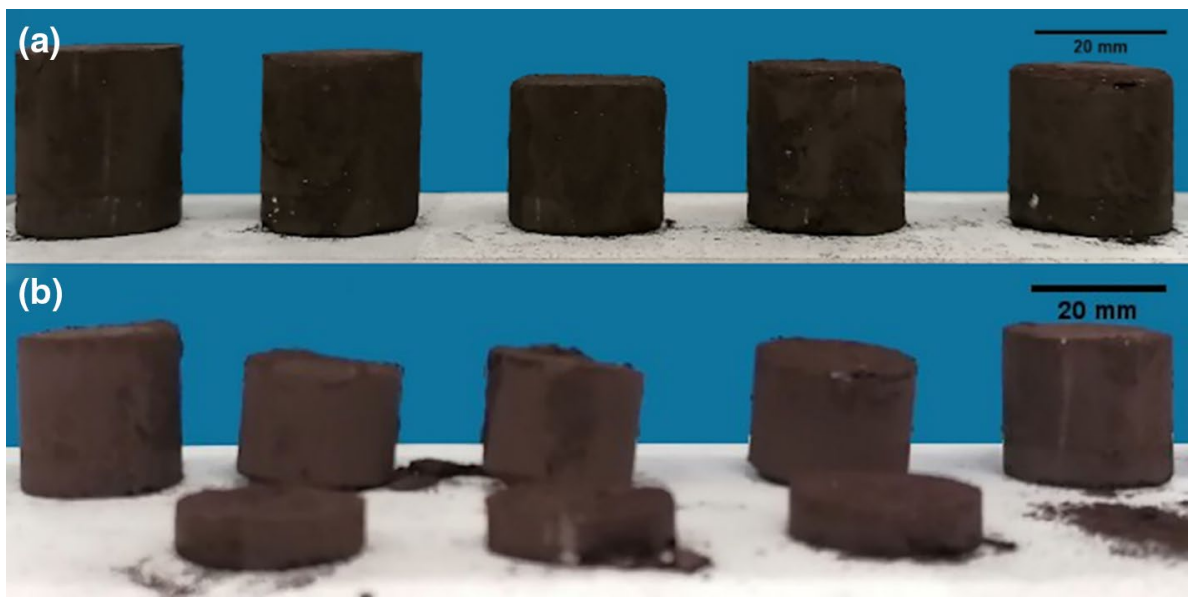


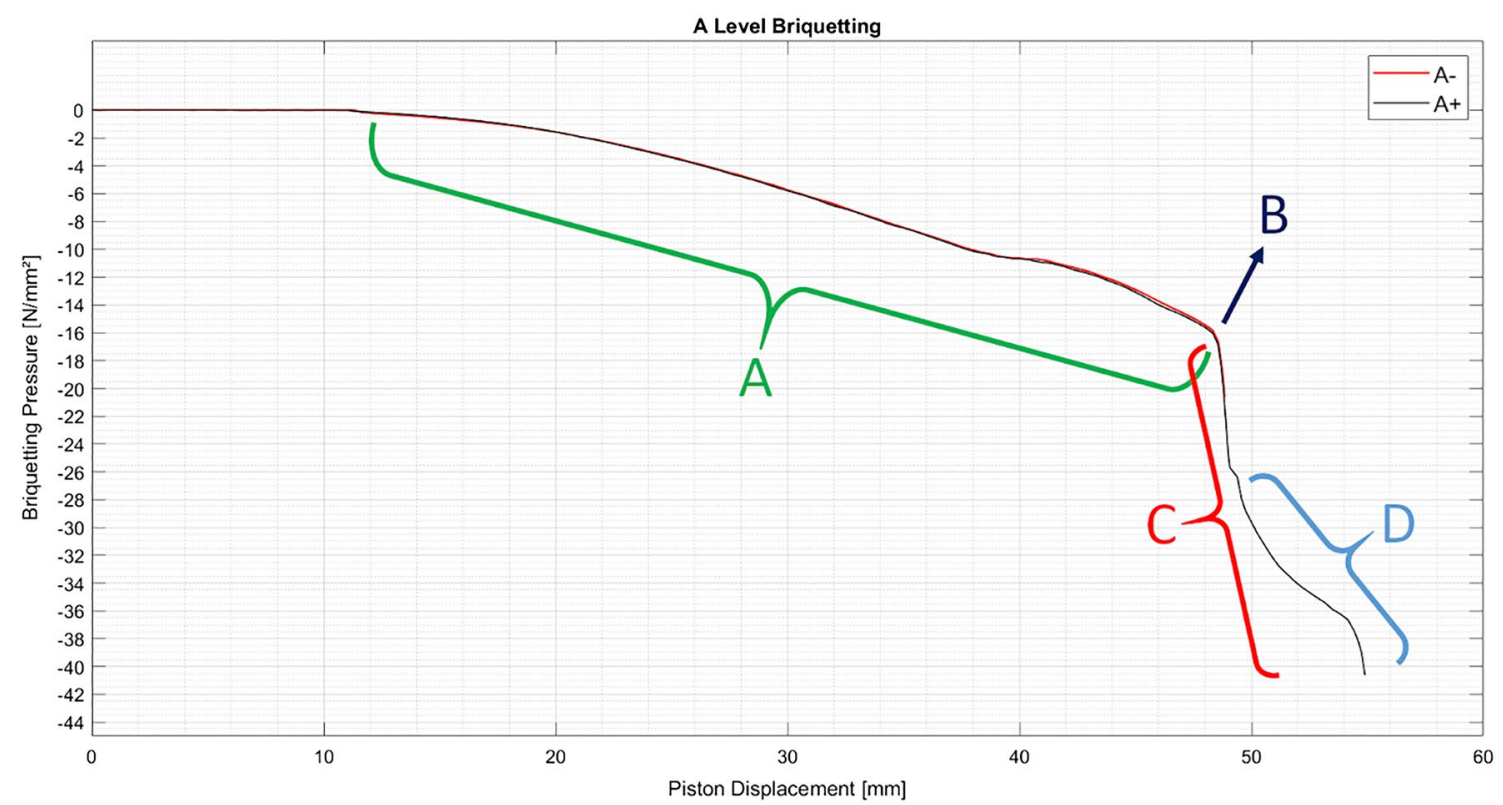

Fig. 6 Briquetting curves of A coded unbound briquettes. A Powder compression alongside the spring deformation; B Spring maximum deformation ( $47 \mathrm{~mm}$ of piston displacement); $\mathrm{C}$ compaction with the spring fully compressed; D inflection due to the entrapped gas release and particles rearrangement at $40 \mathrm{MPa}$
Fig. 7 Briquettes with binder (SJBFS). From the upper to the lower line: $\mathrm{B}+\mathrm{B}-\mathrm{C}-\mathrm{C}+$ briquettes

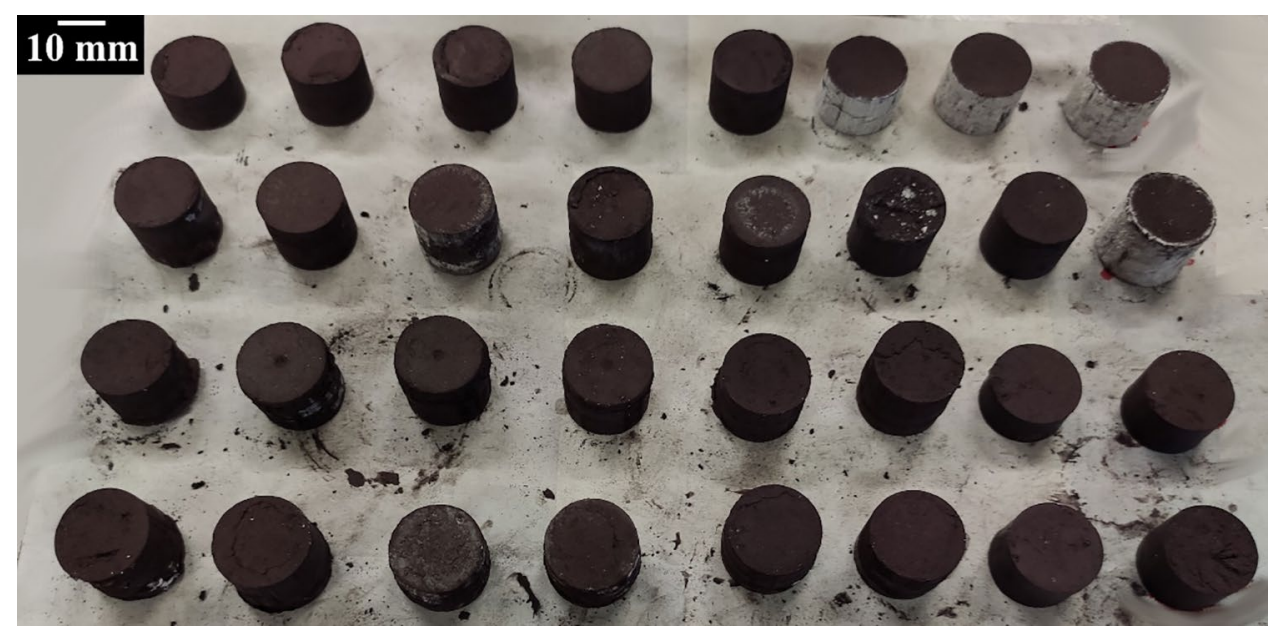

process has the same behavior through the levels up to the point where the spring reaches its maximum displacement, which in the case of the bound briquettes, are close to a piston displacement of $50 \mathrm{~mm}$. The slight increase of the piston displacement up to the spring max deformation is related to the water present in the binder, released during low briquetting pressures throughout the spring compression, demanding a higher displacement of the piston to reach the point of sharp increase of pressures. The briquettes done at $20 \mathrm{MPa}(\mathrm{B}-$ and $\mathrm{C}-$ ) showed the same behavior during production of the unbound briquettes, apart from the slightly higher displacement (segment A and B). On the other hand, the briquettes produced at $40 \mathrm{MPa}(\mathrm{B}+$ and $\mathrm{C}+)$ showed similar behavior between them, with much more expressive inflection at pressures higher than $20 \mathrm{MPa}$ (segment C) compared with the A+briquettes, probably due to a further water release and a possible rearrangement of starch and the JBFS powder at higher pressures [43-46].

Some of the SJBFS briquettes showed the development of a white structure in their walls (in the right upper corner of Fig. 7). This material was collected and analyzed by XRD and SEM and it was identified as thenardite, a crystalline compound composed mostly of $\mathrm{Na}_{2} \mathrm{SO}_{4}$. The sodium sulfate presence can be explained by the non-homogeneous or insufficient heating of the natrojarosite portion of the jarosite during the roasting process, as it is suffers thermal 

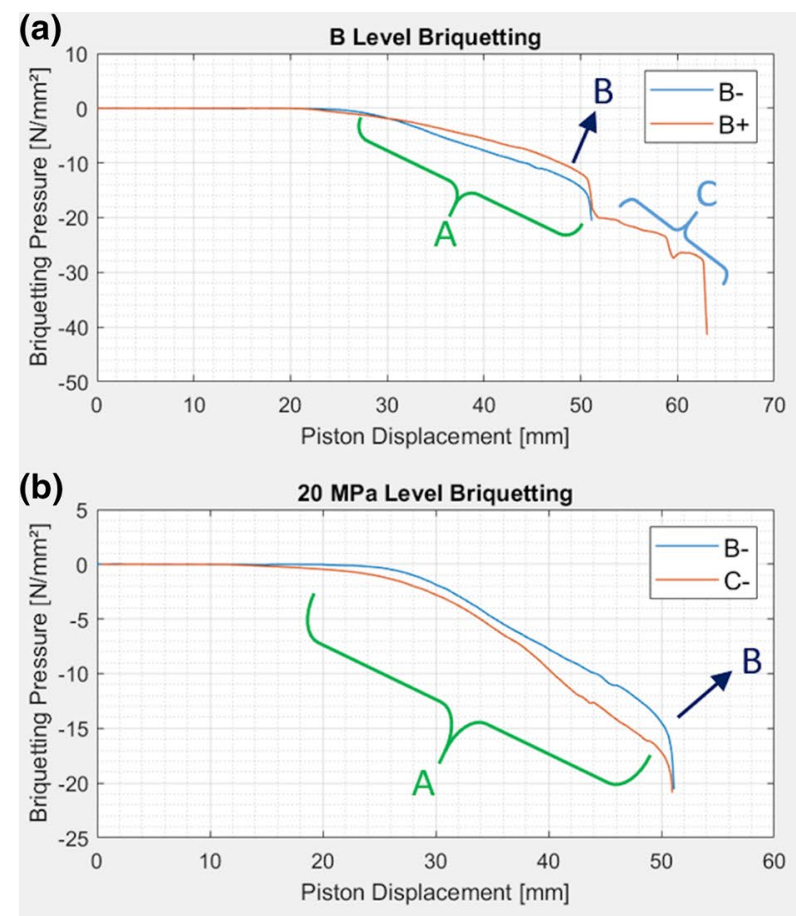

Fig. 8 Briquetting pressures against displacement during the SJBFS briquettes production: (a) comparison between 20 and $40 \mathrm{MPa}$ briquetting pressure at $5 \mathrm{wt} \%$ starch; (b) comparison between 5 and $10 \mathrm{wt} \%$ starch at $20 \mathrm{MPa}$ briquetting pressure; (c) comparison between 20 and $40 \mathrm{MPa}$ briquetting pressure at $10 \mathrm{wt} \%$ starch; (d)

decomposition at nearly $900{ }^{\circ} \mathrm{C}[14,47]$ leaving a small portion of the raw JBFS powder with a residual $\mathrm{Na}_{2} \mathrm{SO}_{4}$ which did not decompose. As the sodium sulfate gets in contact with the water present in the gelatinized starch during the SJBFS production, it dissolves. As the water starts evaporating from the briquettes during drying, the sodium sulfate crystallization into thenardite (anhydrous sodium sulfate) starts to happen [48-50]. At temperatures lower than $32.4{ }^{\circ} \mathrm{C}$, the precipitation of mirabilite $\left(\mathrm{Na}_{2} \mathrm{SO}_{4} \cdot 10 \mathrm{H}_{2} \mathrm{O}\right)$ is expected. However, as described by Rodriguez-Navarro et al., the mirabilite decomposes into thenardite when the air relative humidity drops below $71 \%$, or the solution can even precipitate into thenardite directly at a relative air humidity below $40 \%$ and temperatures of $20^{\circ} \mathrm{C}$ [49]. The growth of both mirabilite and thenardite crystals inside porous structures can be critical due to the high volume increase and pressures involved during it [48-52]. This could be the main factor for which the briquettes that developed such structures during their drying had their mechanical properties hindered, and it will be discussed later.

After processing, the briquettes were left to dry at room temperature. After $72 \mathrm{~h}$ no significant mass changes from water evaporation were observed as for their dimensions. A regression, shown in Fig. 9a, shows the drying behavior of the briquettes, alongside an equation of the fitted curve,
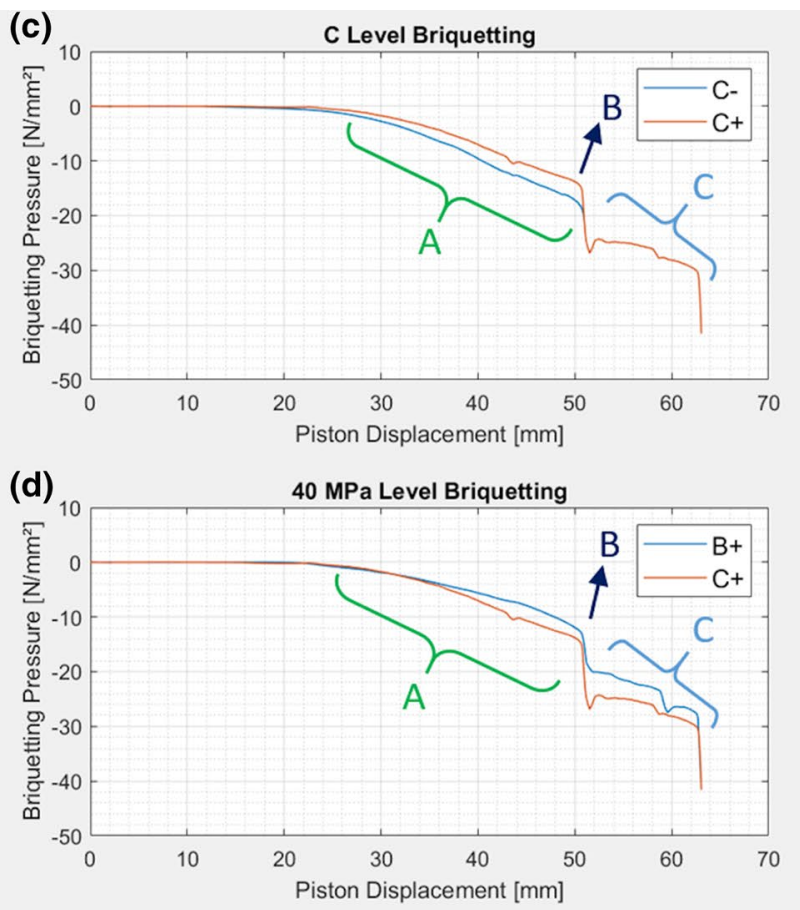

comparison between 5 and $10 \mathrm{wt} \%$ starch at $40 \mathrm{MPa}$ briquetting pressure. A: powder compression alongside the spring deformation; B: spring maximum deformation ( $\sim 50 \mathrm{~mm}$ of piston displacement); $\mathrm{C}$ : inflection where rearrangement of powder and starch happens, together with further water release

confirming that after 3 days of drying, negligible evaporation losses are seen, while after one day, the mass loss ranges from 8 to $12 \%$, and after two days, from 5 to $1 \%$. The analysis of variance (Fig. $9 \mathrm{~b}$ and Table 4 ) highlighted that both the binder amount and briquetting pressure are statistically significative on the mass loss. Note that A coded briquettes are not present in this analysis, due to the absence of the binder. The results show that a higher pressure leads to lower mass loss related to the evaporation, this is due to the removal of the water contained in the starch gel being forced out through the machine gaps by the high machine load, leading to a lower moisture produced briquette. Also, being the starch gelatinized at a ratio 1:6 with water, a briquette with a higher content of binder implies a higher amount of water that leads to a higher loss by evaporation after briquetting.

The density of the briquettes was then assessed just after their production (wet briquettes), and after their drying period. It was found that the wet briquettes showed no significant difference in their density. However, they showed differences regarding their dry density, as shown in Fig. 9c. As expected, higher pressures led to more dense briquettes, which is commonly seen in processes involving briquetting, because there is a better agglomeration of the material and less empty space inside the briquette [53]. As the ANOVA 

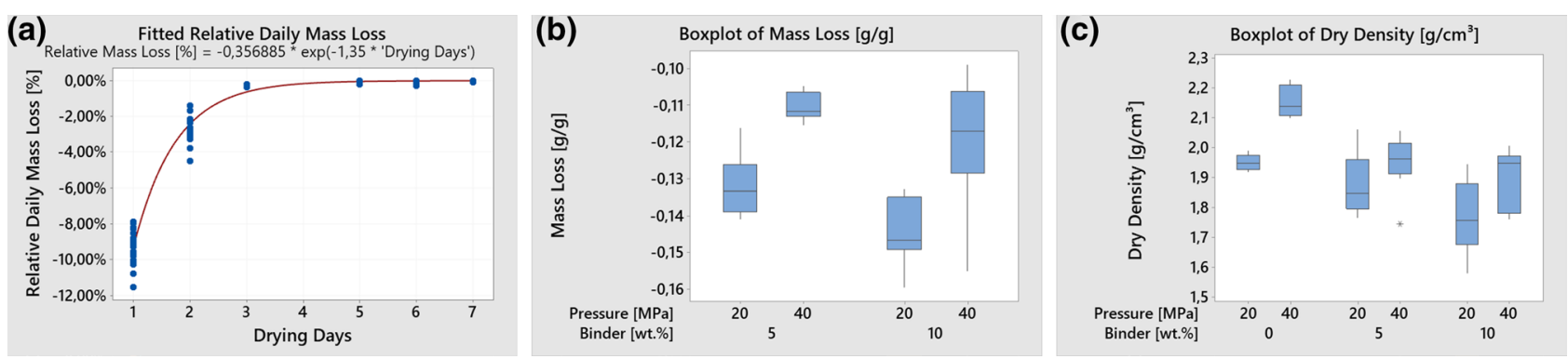

Fig. 9 Fitted curve for the relative mass loss during the drying days (a); boxplot of the briquettes mass loss (b); boxplot of the briquettes dry density (c)

Table 4 ANOVA table regarding the mass loss and dry density analysis

\begin{tabular}{lcccrc}
\hline Source & DF & Adj SS & Adj MS & $F$ value & $P$ value \\
\hline Analysis of variance: mass loss & & & \\
Binder & 1 & 0.000876 & 0.000876 & 7.07 & 0.013 \\
Pressure & 1 & 0.004021 & 0.004021 & 32.46 & 0.000 \\
Binder*Pressure & 1 & 0.000017 & 0.000017 & 0.13 & 0.717 \\
Error & 27 & 0.003344 & 0.000124 & & \\
Total & 30 & 0.008118 & & & \\
Analysis of variance: dry density & & & \\
Binder & 2 & 0.29932 & 0.149659 & 16.65 & 0.000 \\
Pressure & 1 & 0.18473 & 0.184733 & 20.56 & 0.000 \\
Binder*Pressure & 2 & 0.02751 & 0.013755 & 1.53 & 0.230 \\
Error & 36 & 0.32351 & 0.008986 & & \\
Total & 41 & 0.81707 & & & \\
\hline
\end{tabular}

results show (Table 4), the binder also played a role in the density analysis, and this is due to the starch powder being less dense than the JBFS powder, so the higher the amount of binder added, the less dense the briquette will be, and also due to the non-filled spaces left inside the briquettes due to the water evaporation, as the briquettes with binder addition show a trend similar to the mass loss analysis: the higher the mass loss due to the evaporation, the lower the density, as there was no dimensional variation of the briquettes.

As the briquettes dried, an XRD analysis was conducted on three different briquettes, a good $\mathrm{B}+$ and $\mathrm{C}+$, and a $\mathrm{B}+$ briquette developing thenardite (marked as $\mathrm{B}+{ }^{*}$ ). Comparing with the initial composition of the JBFS powder (Fig. 10a), all the three briquettes show the formation of gypsum, a hydrated form of calcium sulfate $\left(\mathrm{CaSO}_{4} \cdot 2 \mathrm{H}_{2} \mathrm{O}\right)$, formed due to the water presence from the binder addition, which dissolves in water as anhydrite and precipitates as gypsum when the briquette dries [54, 55]. Also, a similar phenomenon happens to the iron oxide $\left(\mathrm{Fe}_{2} \mathrm{O}_{3}\right)$, which could have transformed into goethite $(\mathrm{FeO}(\mathrm{OH}))$ by the presence of water [56, 57]. For what concerns the $\mathrm{B}+*$ briquette, both thenardite and natrojarosite were found, which reinforce the assumption that the natrojarosite presence in the powder is an indicative factor of improper heating during the raw jarosite roasting, resulting in the thenardite crystallization in the briquettes due to the presence of $\mathrm{Na}_{2} \mathrm{SO}_{4}$ that did not decompose to $\mathrm{Na}_{2} \mathrm{O}$ during roasting due to insufficient heating (Fig. 10b).

\section{Physical Characterization}

\section{Cold Compression Strength}

Figure 11a and Table 5 show the curves obtained from the cold compression strength (CCS) test. Besides from the B- specimens, which have apparently lower mechanical properties, all the samples seem to be very similar regarding their compression behavior. In Fig. 11b, the comparison among the only JBFS briquette not swelled $(\mathrm{A}+), \mathrm{B}+$ briquettes and a briquette with thenardite $(\mathrm{B}+*)$ is shown. From this plot, it is clear that the latter has a noticeable decrease in the compression resistance in comparison with the $\mathrm{B}+$ briquettes, confirming that the thenardite crystallization hinders the compression resistance. On the other hand, the $\mathrm{B}+{ }^{*}$ briquette CCS is higher than the $\mathrm{A}+$ briquette one, showing that it is preferable to be prone to thenardite crystallization rather than not mixing the gelatinized starch to the JBFS. The starch addition and the increase of mechanical properties can be related to the interaction between the gelatinized starch and the JBFS powder, which leads to a better adhesion between the particles by capillary and molecular forces. Furthermore, the gelatinized starch, containing amylose and amylopectin in amorphous structure could enhance the cohesion between the particles [44, 58-61], leading to a higher resistance during the test.

The binder addition has no statistical influence on the CCS of the briquettes, however, the briquetting pressure can be considered as significant factor, since it has a $P$ value lower than 0.1, leading to a statistical significance for $90 \%$ interval of confidence (Table 6). This can be explained by the fact that higher briquetting pressures leads to higher contact between the powder particles (higher plasticization 

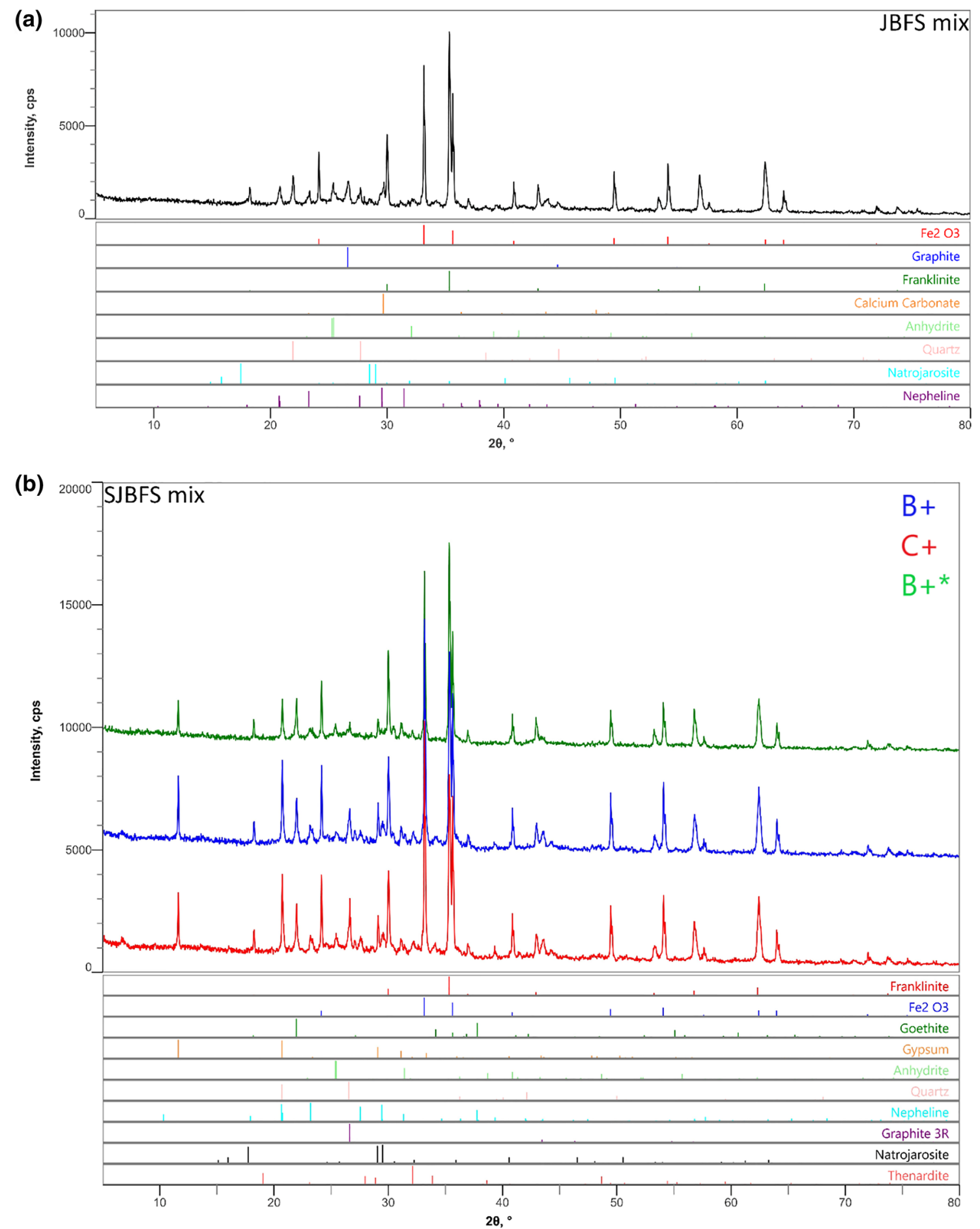

Fig. 10 XRD pattern of the JBFS mix before briquetting (a) and SJBFS briquettes after drying (b)

and fragmentation of particles), which increases the van der Waals and interlocking forces in the briquette [43, 62, 63] as seen in the dry density analysis (paragraph 3.1.2). Comparing with other studies using similar materials [28, 32, $42,62,64-66]$, the briquettes showed good compression strength, having a mean value above $12 \mathrm{MPa}$ for the $40 \mathrm{MPa}$ briquetted specimen, with a maximum value of $16 \mathrm{MPa}$ for $\mathrm{C}+2$ sample, and an axial resistance of more than $250 \mathrm{kgf}$. For instance, Kumar et al. [32] tested briquettes of mill scale and dust with starch as binder, and obtained briquettes resisting $140 \mathrm{kgf}$, while Narita et al. [42] obtained iron ore with coal briquettes that achieved compression strengths not 

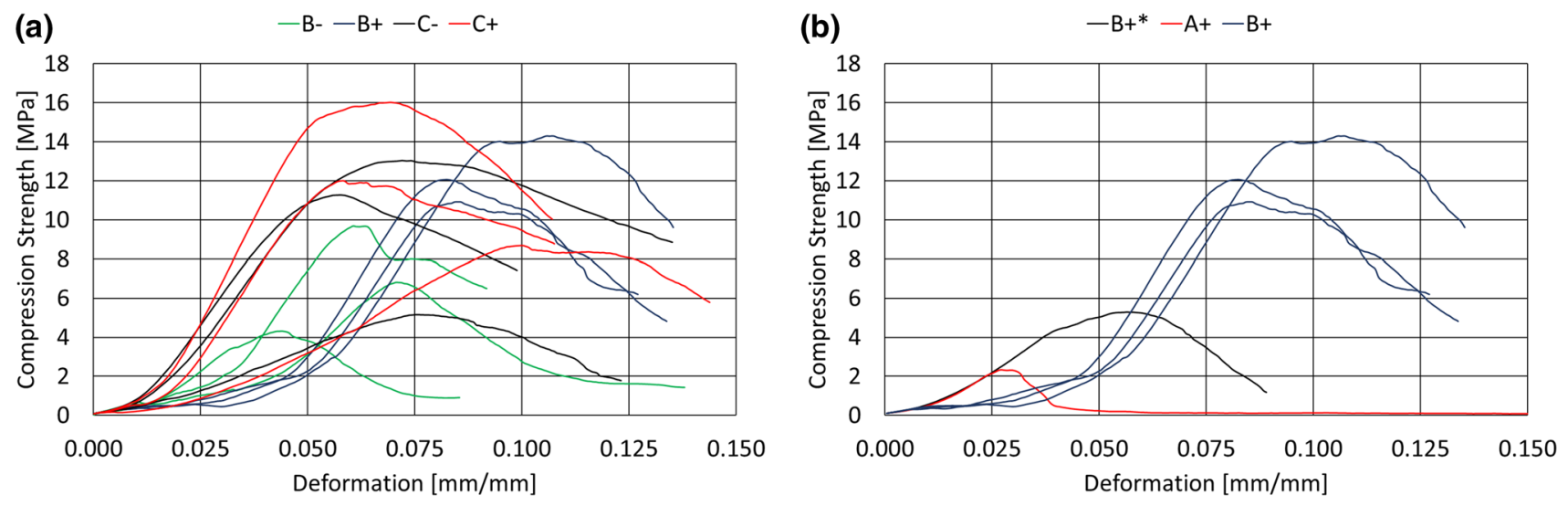

Fig. 11 Cold compression test curves of SJBFS briquettes (a); comparison among JBFS (A+), SJBFS (B+), and a briquette developing thenardite $\left(\mathrm{B}+{ }^{*}\right)(\mathbf{b})$

Table 5 Cold compression test results

\begin{tabular}{lrlll}
\hline Specimen & $\begin{array}{l}\text { Cold } \\
\text { compres- } \\
\text { sion } \\
\text { strength } \\
{[\mathrm{MPa}]}\end{array}$ & $\begin{array}{l}\text { Maximum } \\
\text { load }[\mathrm{kN}]\end{array}$ & $\begin{array}{l}\text { Deformation } \\
{[\mathrm{mm} / \mathrm{mm}]}\end{array}$ & $\begin{array}{l}\text { Energy absorp- } \\
\text { tion }\left[\mathrm{mJ} / \mathrm{mm}^{3}\right]\end{array}$ \\
& 6.81 & 2.14 & 0.071 & 0.166 \\
B-1 & 4.31 & 1.35 & 0.044 & 0.089 \\
B-2 & 9.70 & 3.05 & 0.061 & 0.237 \\
$\mathrm{~B}-3$ & 12.06 & 3.79 & 0.082 & 0.313 \\
$\mathrm{~B}+1$ & 10.92 & 3.43 & 0.085 & 0.299 \\
$\mathrm{~B}+2$ & 14.30 & 4.49 & 0.107 & 0.565 \\
$\mathrm{~B}+3$ & 5.15 & 1.62 & 0.076 & 0.188 \\
$\mathrm{C}-1$ & 13.03 & 4.09 & 0.072 & 0.492 \\
$\mathrm{C}-2$ & 11.27 & 3.54 & 0.058 & 0.336 \\
$\mathrm{C}-3$ & 8.69 & 2.73 & 0.100 & 0.372 \\
$\mathrm{C}+1$ & 16.03 & 5.04 & 0.069 & 0.598 \\
$\mathrm{C}+2$ & 12.00 & 3.77 & 0.058 & 0.295 \\
$\mathrm{C}+3$ & 6.94 & 2.18 & 0.058 & 0.164 \\
Mean B- & 12.43 & 3.90 & 0.092 & 0.392 \\
Mean B+ & 9.82 & 3.08 & 0.068 & 0.339 \\
Mean C- & 12.24 & 3.85 & 0.076 & 0.422 \\
Mean C+ & 10.36 & 3.25 & 0.074 & 0.329 \\
Total mean & 2.32 & 0.73 & 0.021 & 0.038 \\
A+ & 5.29 & 1.66 & 0.056 & 0.148 \\
B+* & & & & \\
\hline & & & & \\
\hline
\end{tabular}

higher than $5 \mathrm{MPa}$ before heat treatment, evidencing the strength of the briquettes in the present study. One key factor that might also influence positively the strength of the briquettes compared to the mentioned studies is the particle size of the SJBFS used being not higher than $0.125 \mu \mathrm{m}$, which increases contact area between particles during briquetting and the van der Waals forces consequently.

As shown in Table 5, the deformation of each briquette at the maximum compressive strength was also calculated,
Table 6 ANOVA table regarding CCS, deformation, and energy absorption

\begin{tabular}{|c|c|c|c|c|c|}
\hline Source & DF & Adj SS & Adj MS & $\begin{array}{l}F \\
\text { value }\end{array}$ & $\begin{array}{l}P \\
\text { value }\end{array}$ \\
\hline \multicolumn{6}{|c|}{ Analysis of variance: cold compression strength } \\
\hline Binder & 1 & 5.439 & 5.439 & 0.53 & 0.486 \\
\hline Pressure & 1 & 46.939 & 46.939 & 4.60 & 0.064 \\
\hline Binder*pressure & 1 & 7.052 & 7.052 & 0.69 & 0.430 \\
\hline Error & 8 & 81.695 & 10.212 & & \\
\hline Total & 11 & 141.124 & & & \\
\hline \multicolumn{6}{|c|}{ Analysis of variance: deformation } \\
\hline Binder & 1 & 0.000025 & 0.000025 & 0.11 & 0.753 \\
\hline Pressure & 1 & 0.001221 & 0.001221 & 5.20 & 0.052 \\
\hline Binder*Pressure & 1 & 0.000501 & 0.000501 & 2.13 & 0.183 \\
\hline Error & 8 & 0.001880 & 0.000235 & & \\
\hline Total & 11 & 0.003627 & & & \\
\hline \multicolumn{6}{|c|}{ Analysis of variance: energy absorption } \\
\hline Binder & 1 & 0.03126 & 0.03126 & 1.65 & 0.235 \\
\hline Pressure & 1 & 0.07257 & 0.07257 & 3.83 & 0.086 \\
\hline Binder*Pressure & 1 & 0.01571 & 0.01571 & 0.83 & 0.389 \\
\hline Error & 8 & 0.15160 & 0.01895 & & \\
\hline Total & 11 & 0.27113 & & & \\
\hline
\end{tabular}

which have the same trend of the CCS. Even in this case the binder has no statistical influence on the deformation, whereas the pressure has a $P$ value lower than 0.1 , highlighting that it may be influential, probably due to the higher adhesion and van der Waals forces between the particles that allow a higher energy absorption as deformation (Table 6).

Finally, by calculating the area of the compression curve, the energy absorption of the briquette during the compression could be calculated up to the CCS point (Table 5). Also, in this case, only the pressure have a $P$ value under 
0.1 , meaning that starch as a binder may not promote higher mechanical properties, whereas briquetting pressure is still significant for the same reasons said previously (Table 6).

Figure 12 shows the difference between a B- and a $\mathrm{B}+$ briquette after the compression test. The former appears much more damaged after the test, whereas the latter shows how the pressure influences the agglomeration of the powder.

\section{Tumbler and Abrasion Test}

The tumbler and abrasion test are performed to simulate the briquettes resistance through processes like conveyor belts charging and transporting. Two main destructive phenomena are observed: the drop damage, as the briquettes are constantly falling from the top to the bottom of the tumbler and the abrasive phenomena, as the briquettes slip and/or rotate in the wall of the tumbler, interacting or not with each other.

The results presented in Table 7 show that the briquettes tumbler index and abrasion index are similar for 200 and 400 rotations. However, in the case of the $\mathrm{B}+$ tested briquettes, they have suffered a big loss after 700 rotations, due do the disintegration of one of the tested briquettes (Fig. 13a). In particular, this latter $\mathrm{B}+$ briquette has shown a white color in its side wall, which can be related to an uneven distribution of the binder inside the matrix due to an improper starch gelatinization that hindered the binding properties. For this reason, two more briquettes, labeled as $\left(\mathrm{B}+{ }^{*}\right)$ were tested again, with results comparable with the other specimens. All the other briquettes showed good results during the tests, with good abrasion and tumbler index, especially the B- briquettes (Table 7). Both abrasion and tumbler indexes may have a linear relationship with the number of rotations up to 700 rotations, except in the case where there is a defective briquette. Moreover, the $\mathrm{C}+$ and $\mathrm{C}-$ briquettes showed similar trends in both tests, giving a hint that maybe the

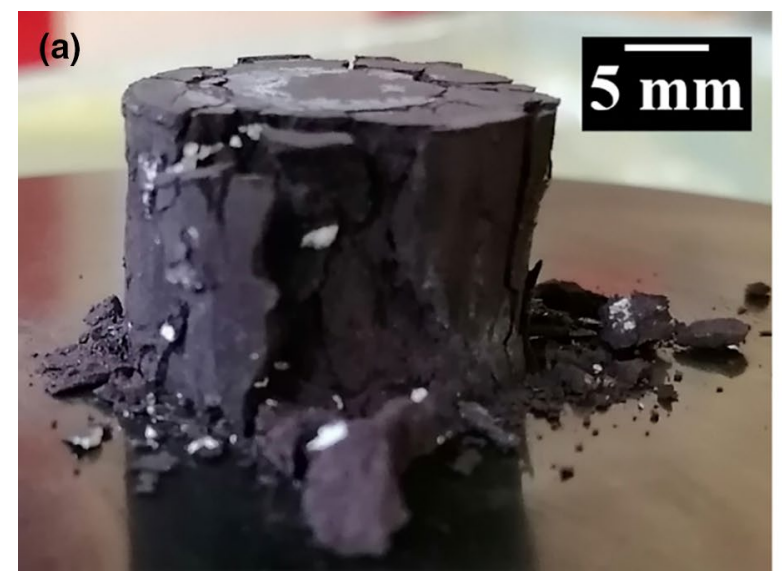

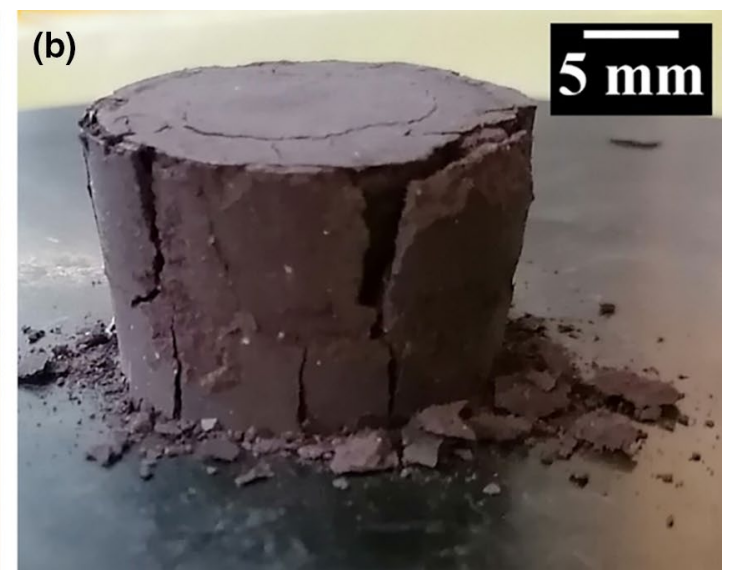

pressure does not influence the abrasion resistance, but since the experiments are not replicated, an ANOVA analysis was not possible. The $\mathrm{B}+{ }^{*}$ showed the lowest performance during the test, possibly due to thenardite crystallization that lowers its mechanical properties. However, the binding forces provided by the properly gelatinized starch during its production were enough to keep the briquettes integrity (Fig. 13b), making it still suitable for use.

The tumbler index after 200 rotations was higher than $90 \%$ for all the briquettes, showing their good resistance to abrasion if compared to briquettes with similar composition (iron oxide and/or carbon sources) from other studies [61, 67, 68]. Rocha Lemos et al. [61] characterized pillow and cylindrical briquettes made of blast furnace sludge and dust with different binders, the results showed that by increasing the sludges fraction, the abrasion resistance of the briquettes increases, as most of the briquettes with a higher fraction of sludges were retained by more than $90 \%$ of their

Table 7 Abrasion and tumble indexes and fine fraction $(<500 \mathrm{~mm})$ for each rotation and briquette level

\begin{tabular}{llllll}
\hline Sample & B- & B+ & B+* & C- & C+ \\
\hline Rotations & \multicolumn{4}{l}{ Abrasion index } \\
200 & $1.5 \%$ & $2.7 \%$ & $3.9 \%$ & $2.9 \%$ & $2.3 \%$ \\
400 & $2.5 \%$ & $6.3 \%$ & $5.0 \%$ & $4.2 \%$ & $4.0 \%$ \\
700 & $3.7 \%$ & $26.4 \%$ & $6.4 \%$ & $5.7 \%$ & $5.9 \%$ \\
& Tumbler index \\
200 & $98.0 \%$ & $96.9 \%$ & $91.4 \%$ & $92.3 \%$ & $95.9 \%$ \\
400 & $96.7 \%$ & $93.0 \%$ & $89.7 \%$ & $90.0 \%$ & $93.0 \%$ \\
700 & $95.4 \%$ & $57.4 \%$ & $88.1 \%$ & $87.9 \%$ & $90.1 \%$ \\
700 & Fine fraction $(<500 \mu m)$ & & \\
400 & $1.44 \%$ & $2.14 \%$ & $2.90 \%$ & $2.00 \%$ & $2.01 \%$ \\
700 & $2.40 \%$ & $5.20 \%$ & $4.17 \%$ & $3.45 \%$ & $3.43 \%$ \\
& $3.52 \%$ & $23.86 \%$ & $5.69 \%$ & $5.10 \%$ & $4.30 \%$ \\
\hline
\end{tabular}

Fig. $12 \mathrm{~B}-$ briquette (a) and $\mathrm{B}+$ briquette (b), after the test 

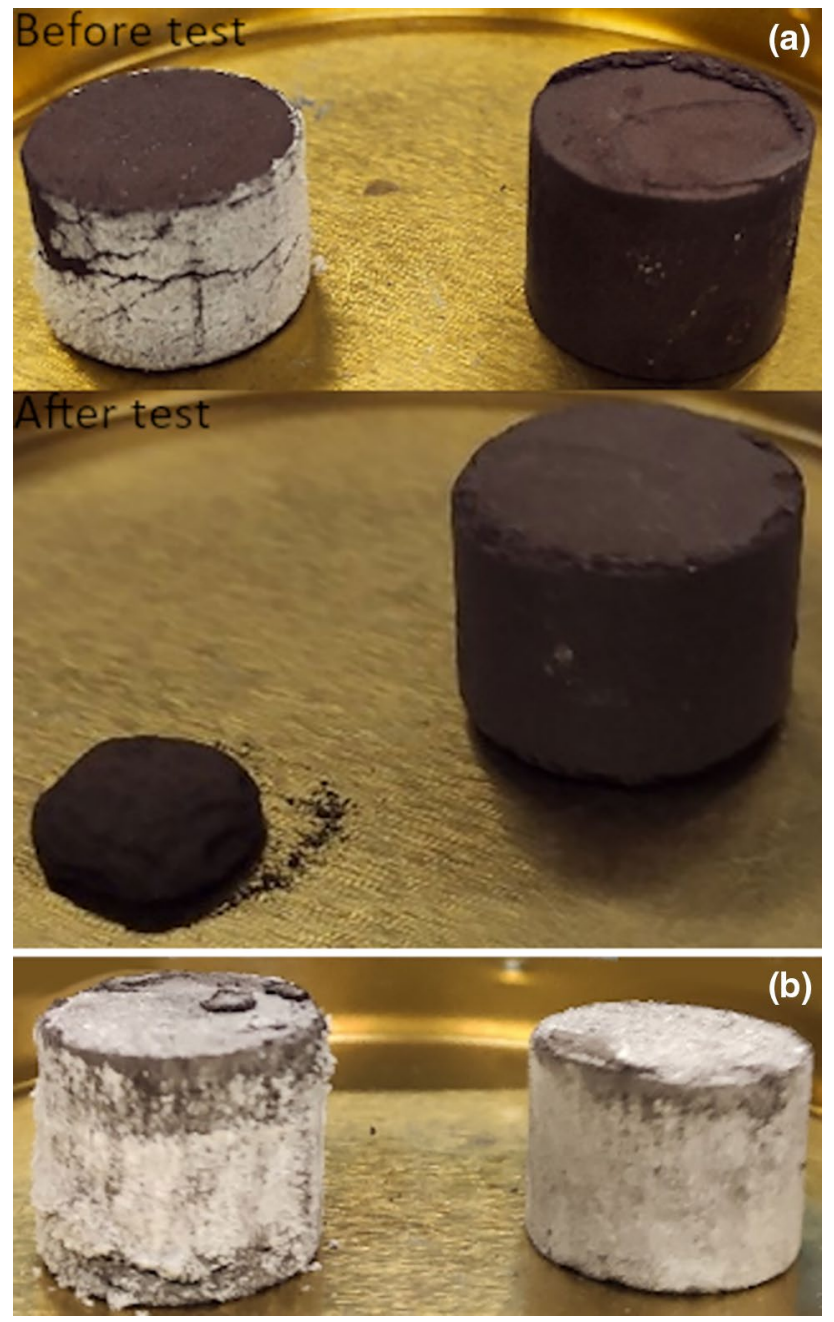

Fig. $13 \mathrm{~B}+$ briquettes before and after 700 runs tumbler and abrasion test (a); $\mathrm{B}+*$ briquette before tumbler and abrasion test $(\mathbf{b})$

cumulative mass by a sieve with $7.5 \mathrm{~mm}$ aperture, highlighting the sludges agglomeration and resistance features. In the case of the $\mathrm{B}-$ and $\mathrm{C}+$ briquettes, the tumbler index remained higher than $90 \%$ after 700 rotations, showing that the gelatinized starch is a suitable binder for achieving a suitable abrasion resistance.

However, being the equipment and the conditions not standardized, the obtained results can be only qualitatively compared with the literature ones. For this reason, a control test was performed by tumbling some ferroalloy stones (FA). The tumbler index of FA passed from 99.56 after 200 runs to 99.05 after 700 runs, while the abrasion index varied from 0.37 to 0.94 , therefore demonstrating high resistance to abrasion and crushing as can be expected by a stony material. To be an agglomerate, the produced and tested briquettes behave similarly to FA, especially the $\mathrm{B}$ - samples, once again demonstrating the high cold resistance reached by the agglomeration process.
Moreover, all the briquettes did not have a cumulative mass of fines largely higher than $5 \%$ passing through the $0.5 \mathrm{~mm}$ sieve. After 700 rotations, both $\mathrm{B}-$ and $\mathrm{C}+$ briquettes showed cumulative masses lower than $5 \%$. Therefore, they can be considered the best combinations regarding possible fine powder losses. The $\mathrm{B}+$ level had a low performance after 700 rotations, like the abrasion index, due to the disintegration of one of the briquettes, demonstrating that a non-properly bound briquette may be problematic not only mechanically, but also for the environment, as these powders could be dispersed during transportation.

\section{Drop Test}

The drop test is a good qualitative analysis to provide a parameter for the loading and unloading of briquettes inside a cargo vehicle, or the briquettes loading inside a furnace. The drop tests were performed with two of each $C$ level briquettes, and three B level briquettes. Also, four briquettes, two from the $\mathrm{B}+$ level and two from the $\mathrm{B}-$ level showed thenardite precipitation in their side, so they were tagged as $\mathrm{B}+*, \mathrm{~B}+* *, \mathrm{~B}-*$, and $\mathrm{B}-* *$.

Table 8 shows the drop test results for each briquette. The size stability factor is calculated according to the ASTM D440-07:2019, which provides a lower weigh for the fine powder collected in the lower sieve apertures, so the effects of powder detachment and briquette cracking are not very significant in this analysis, as the mass dropped in each test is very low compared to the defined by the standard. The size stability average value for each level is higher in the case of higher compressing pressures during briquetting. Moreover, this test does not take into account how many drops it takes to break apart the briquette. Except for the thenardite containing briquettes, which shattered apart in less than five drops, the remaining specimens resisted at least ten drops prior to breaking into smaller pieces. These effects are better visualized by the impact resistance index (IRI) and adjusted impact resistance index (AIRI), which highlights the lower impact resistance from the briquettes with thenardite crystallization.

The IRI and number of drops for the briquettes with no thenardite crystallization were very good. When a comparison is done with studies with similar materials and testing methods [28, 40, 60, 65, 69], the IRI values obtained are considered more than satisfactory for the briquettes handling and transportation, highlighting the binding power of the starch together with the JBFS powder. Indeed, the IRI threshold for a good briquette is $50[40,41]$ while the current briquettes have IRI values from 10 to 20 times higher. Han et al. [60] produced briquettes of blast furnace dust with several binders, and the ones with corn starch were the ones that resisted the most at ambient temperature, with the average number of falls before breakage being 6 from a $0.5 \mathrm{~m}$ 
Table 8 Drop test results of each specimen

\begin{tabular}{lllllll}
\hline Specimen & Drops & Pieces & IRI & $\begin{array}{l}\text { Correction } \\
\text { factor }\end{array}$ & Adjusted IRI & Size Stability \\
\hline B+ & 10 & 1 & 1000 & 0.87 & 870 & $96 \%$ \\
B+* & 2 & 4 & 50 & 0.56 & 28 & $89 \%$ \\
B+** & 3 & 2 & 150 & 0.97 & 145.5 & $98 \%$ \\
B- & 10 & 1 & 1000 & 0.61 & 610 & $89 \%$ \\
B-* & 2 & 5 & 40 & 0.52 & 21 & $91 \%$ \\
B-** & 4 & 5 & 80 & 0.60 & 48 & $86 \%$ \\
C+ & 10 & 2 & 500 & 0.60 & 300 & $89 \%$ \\
C+ & 10 & 2 & 500 & 0.85 & 425 & $96 \%$ \\
C- & 10 & 2 & 500 & 0.77 & 385 & $90 \%$ \\
C- & 10 & 2 & 500 & 0.52 & 260 & $85 \%$ \\
\hline
\end{tabular}

*Briquette affected by thenardite precipitation and poor binding

** Briquette affected by only thenardite precipitation high drop, Wu et al. [69] produced briquettes of EAF dust and anthracite with bentonite as binder, the biggest value of drop number was 8.2 , with drops of $0.5 \mathrm{~m}$ high also, whereas in the present study, the B briquettes with no thenardite survived 10 drops at $1.63 \mathrm{~m}$ high drops, demonstrating high resilience.

The briquettes with thenardite, however, show low IRI values like happened during the abrasion analysis. However, two different behaviors were observed. $\mathrm{B}-*$ and $\mathrm{B}+*$ samples show IRI values below the threshold, confirming that alongside the lowering of the mechanical properties due to the thenardite, the starch binding of the JBFS matrix did not happen properly as hypothesized in the Sect. Tumbler and Abrasion Test. Also, the size stability was compromised, being the powder detachment significantly high. On the contrary, $\mathrm{B}-* *$ and $\mathrm{B}+* *$ samples show an IRI value above the threshold and also an improved size stability, showing that the gelatinized starch generated good agglomeration of the powder, and the mechanical properties regarding the drop resistance of the briquette were mostly compromised due to possible cracks inside the briquettes matrix promoted by the thenardite crystallization.

Thus, the reason for such poor mechanical property hindering is the same as explained in the paragraph 3.1.2, as the thenardite crystallization generates high internal pressures inside the briquette, which when not properly bound, is not minimally capable of sustaining mechanical loads and impacts. Figure 14 shows the comparison of the briquette matrix of the $\mathrm{B}+$ (Fig. 14a) and the $\mathrm{B}+{ }^{*}$ (Fig. 14b) briquettes after the test, and it is possible to observe cracks inside the $\mathrm{B}+*$ matrix, with small white structures inside it, while the $\mathrm{B}+$ briquette seems more homogeneous and without cracks.

\section{Decrepitation Test and Metallurgical Performances}

The decrepitation test is used to assess the briquettes resistance due to sharp temperature increases, it provides better
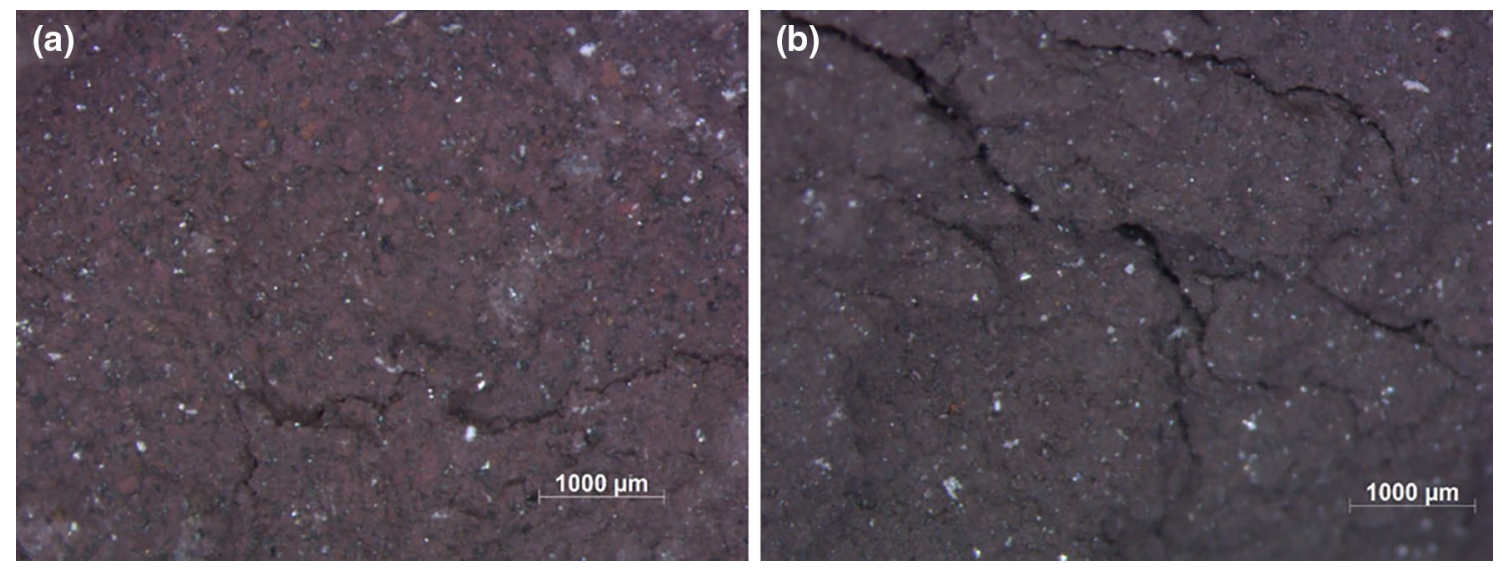

Fig. 14 Comparison between the B+dropped briquettes: (a) properly bound briquette after 10 drops; (b) improperly bound briquette with thenardite crystallization 
understanding of how the briquettes would behave during charging in a hot furnace. The decrepitation index $\left(\mathrm{DI}_{6.7}\right)$, the mass retained at the sieves, and the loss of ignition are shown in Table 9. It appears that the $\mathrm{C}$ coded briquettes have very poor performance regarding the decrepitation, as their indexes are very high. However, this low performance compared to the $\mathrm{B}$ coded briquettes can be attributed to the fact that the $\mathrm{C}$ coded briquettes were characterized by some defects and cracks, which led to their collapse at higher temperatures, explaining this discrepancy, which is not present in the previous tests. The briquetting pressure, as in the compression test, seems to have an important role to keep the briquettes integrity in high temperatures by comparing only through the same binder level.

Table 9 Decrepitation index, mass retained, and loss of ignition

\begin{tabular}{lrrrrl}
\hline Specimen & \multicolumn{1}{c}{$\mathrm{DI}_{6.7}$} & \multicolumn{1}{c}{$\mathrm{DI}_{4}$} & \multicolumn{1}{c}{$\mathrm{DI}_{2}$} & \multicolumn{1}{c}{$\mathrm{DI}_{0.5}$} & L.O.I \\
\hline B- & $9.26 \%$ & $8.29 \%$ & $7.50 \%$ & $6.15 \%$ & $16.3 \%$ \\
B+ & $0.94 \%$ & $0.94 \%$ & $0.94 \%$ & $0.30 \%$ & $16.4 \%$ \\
C- & $39.88 \%$ & $37.85 \%$ & $30.73 \%$ & $12.79 \%$ & $20.3 \%$ \\
C+ & $33.03 \%$ & $29.88 \%$ & $22.66 \%$ & $11.45 \%$ & $21.0 \%$ \\
\hline
\end{tabular}

The loss of ignition was higher for the $\mathrm{C}$ coded briquettes, due to higher amount of binder and water mixed during the briquette production compared to the B coded ones. At high temperature, the starch decomposed as the water captured by its polymeric chains evaporated, explaining the higher losses during the test. This water evaporation can lead to higher internal pressures compared to the $\mathrm{B}$ coded briquettes, explaining the lower performance compared to the $\mathrm{B}$ briquettes. Figure 15 shows the briquettes after the test, it can be noticed that the $\mathrm{B}+$ briquette integrity after the test is remarkably higher compared to the others, as its appearance, which has not become darker, unlike the other briquettes, especially the $\mathrm{C}-$ one. Comparing the results with the ones of other studies using similar materials and test methodology $[67,70]$, the $B+$ briquette had outstanding performance, whereas the other briquettes had similar results compared with the literature.

After the test, the $\mathrm{B}+, \mathrm{B}-$, and $\mathrm{C}-$ specimens were submitted to an XRD analysis so as to identify the species formed inside it, the obtained spectra are shown in Fig. 16. From the analysis, it is possible to note that there are no hematite nor goethite, as they were reduced into magnetite by the carbon present in the blast furnace sludges. Furthermore, the presence of other compounds such as
Fig. 15 Briquettes after the decrepitation test: (a) $\mathrm{B}+;$ (b) $\mathrm{C}+$; (c) $\mathrm{B}-;$; d $\mathrm{C}-$
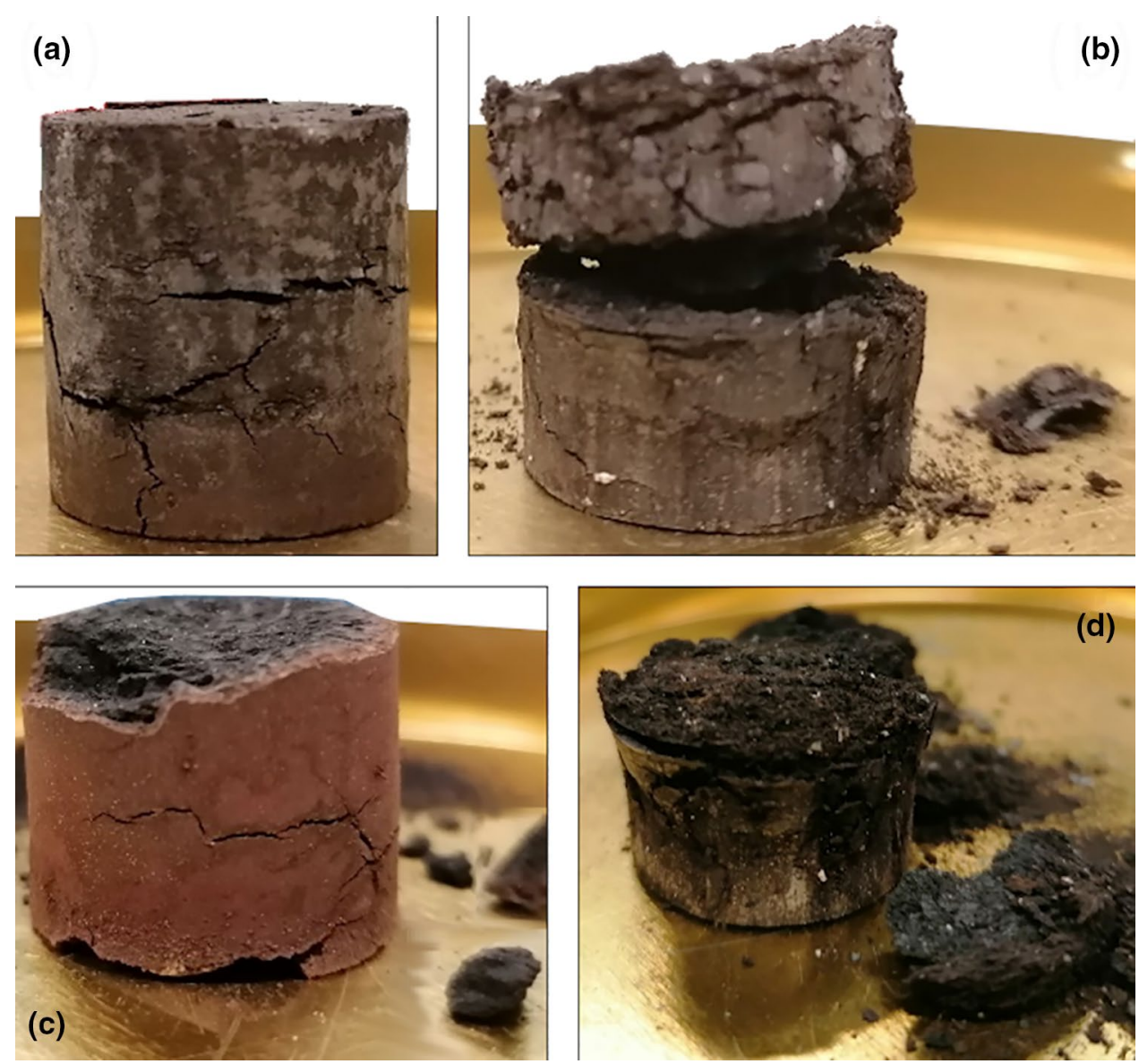


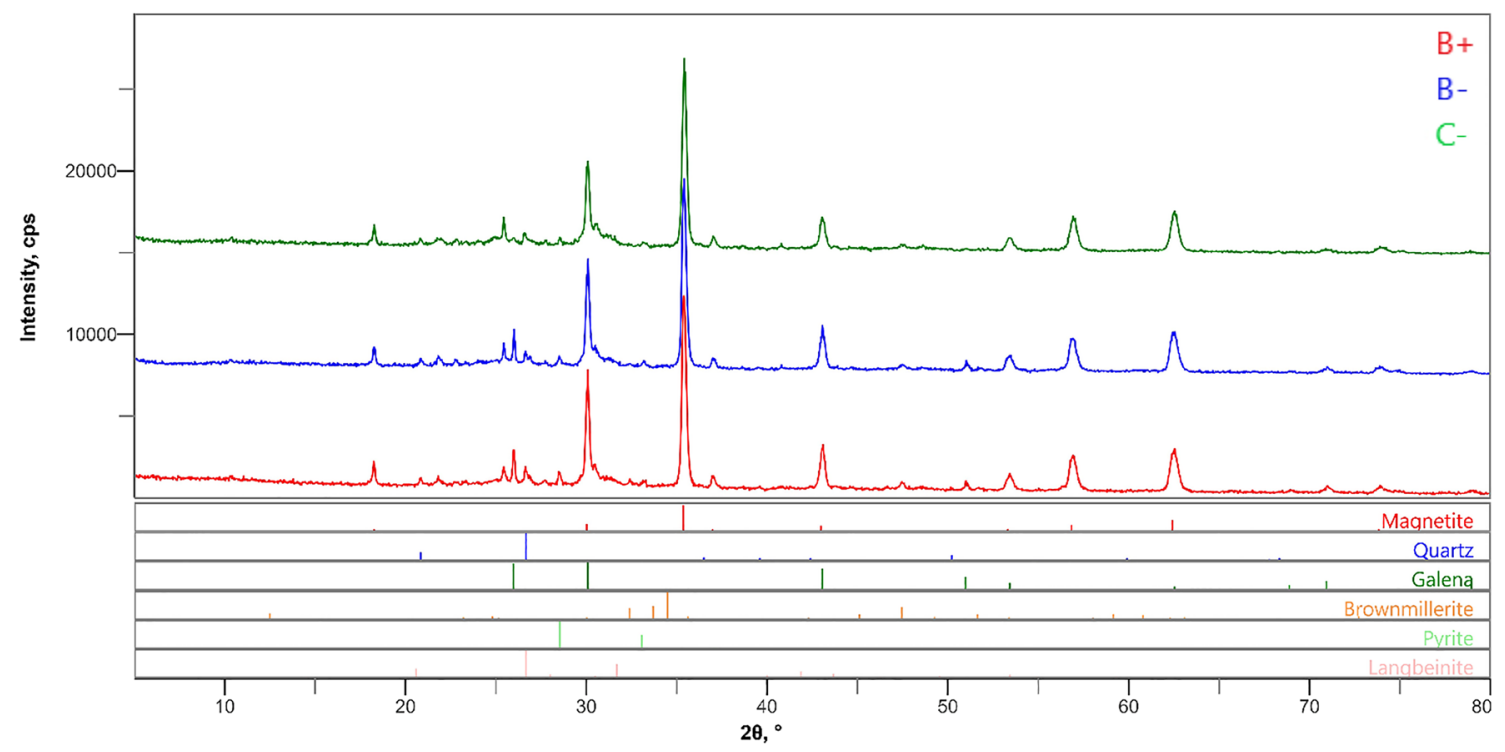

Fig. $16 \mathrm{XRD}$ of the specimen after the decrepitation test

brownmillerite $\left(\mathrm{Ca}_{2}(\mathrm{Al}, \mathrm{Fe})_{2} \mathrm{O}_{5}\right)$ and langbeinite $\left(\mathrm{K}_{2}(\mathrm{Ca}, \mathrm{Mg})\right.$ $\left.\left(\mathrm{SO}_{4}\right)_{3}\right)$, is explained by the reaction among calcium sulfate, magnesium oxide and potassium oxide, coming from the jarosite roasting [14]. There is also the presence of galena $(\mathrm{PbS})$ which is by the reduction of $\mathrm{PbSO}_{4}$ by carbon monoxide, according to Eq. $8[71,72]$ :

$\mathrm{PbSO}_{4}+4 \mathrm{CO} \rightarrow \mathrm{PbS}+4 \mathrm{CO}_{2}$

Finally, the traces of pyrite (FeS) are probably formed following the reaction of hematite and concentrated sulfur species [14, 73].

By exposing the self-reducing briquettes at high temperature in inert atmosphere, iron formation was detected through XRD analysis (Fig. 17), demonstrating the selfreducing capability of the produced material. Some differences can be highlighted from the samples treated at 1000 and $1200{ }^{\circ} \mathrm{C}$. At $1000{ }^{\circ} \mathrm{C}$ iron formation is accompanied by a partial reduction of the original hematite that leads to the formation of wustite. Sulfur-rich compounds are detectable like sphalerite and wurtzite, probably due to the solid-state reaction between gypsum, reduced franklinite, hematite, and goethite. $\mathrm{Zn}$ is also present in hardystonite, probably due to the reaction among gypsum, franklinite, and quartz. Metallic lead is also formed thanks to the final reduction of galena operated by $\mathrm{CO}$, passing though the formation of $\mathrm{PbO}$ (Eqs. 9 and 10). A slag composed by gehlenite and albite characterized the remaining material. These two compounds were already observed during the roasting of loose powders mix by the same authors [23]. An overall mass loss of 39 wt $\%$ was registered, in good agreement with the TG-DSC analysis conducted on loose powder mix by the same authors [23].

$2 \mathrm{PbS}+3 \mathrm{O}_{2} \rightarrow 2 \mathrm{PbO}+2 \mathrm{SO}_{2}$

$\mathrm{PbO}+\mathrm{CO} \rightarrow \mathrm{Pb}+\mathrm{CO}_{2}$

At $1200{ }^{\circ} \mathrm{C}$, the number of compounds still present in the residual briquettes diminished significantly. The residue is formed by iron, magnetite, gehlenite, and oldhamite. By the higher thermal level, all the sulfides compounds were reduced and passed into the iron fraction as sulfides, as detected in the previous research [14, 23]. Lead and zinc were completely volatilized, as a typical white crystal oxide was collected in the exhaust gas system of the oven. Moreover, an overall mass loss of $53 \mathrm{wt} \%$ was registered. This higher mass loss than the mass loss measured at $1000{ }^{\circ} \mathrm{C}$ can be attributed to the vaporization of volatile metals $(\mathrm{Zn}, \mathrm{Pb})$ and to a higher degree of metallization. The residual fraction of magnetite is due to a partial reoxidation caused by a non-perfect fluxing of the inert atmosphere and a thermal level higher than at $1000{ }^{\circ} \mathrm{C}$.

The obtained results are encouraging since they demonstrate that by charging these briquettes in a reducing atmosphere, like the one be present in a Midrex shaft or in a cupola furnace, the reduction of iron oxide will be complete.

Metallurgical performances of $\mathrm{B}+$ briquettes were evaluated through the definition of low-temperature disintegration index, swelling index, and reducibility. The low-temperature disintegration index was evaluated by tumbling some briquettes after exposure at $760{ }^{\circ} \mathrm{C}$ for $30 \mathrm{~min}$ in a controlled 
Fig. 17 XRD of $\mathrm{B}+$ briquettes heat treated at (a) $1000{ }^{\circ} \mathrm{C}$ and (b) $1200{ }^{\circ} \mathrm{C}$ under fluxed argon atmosphere
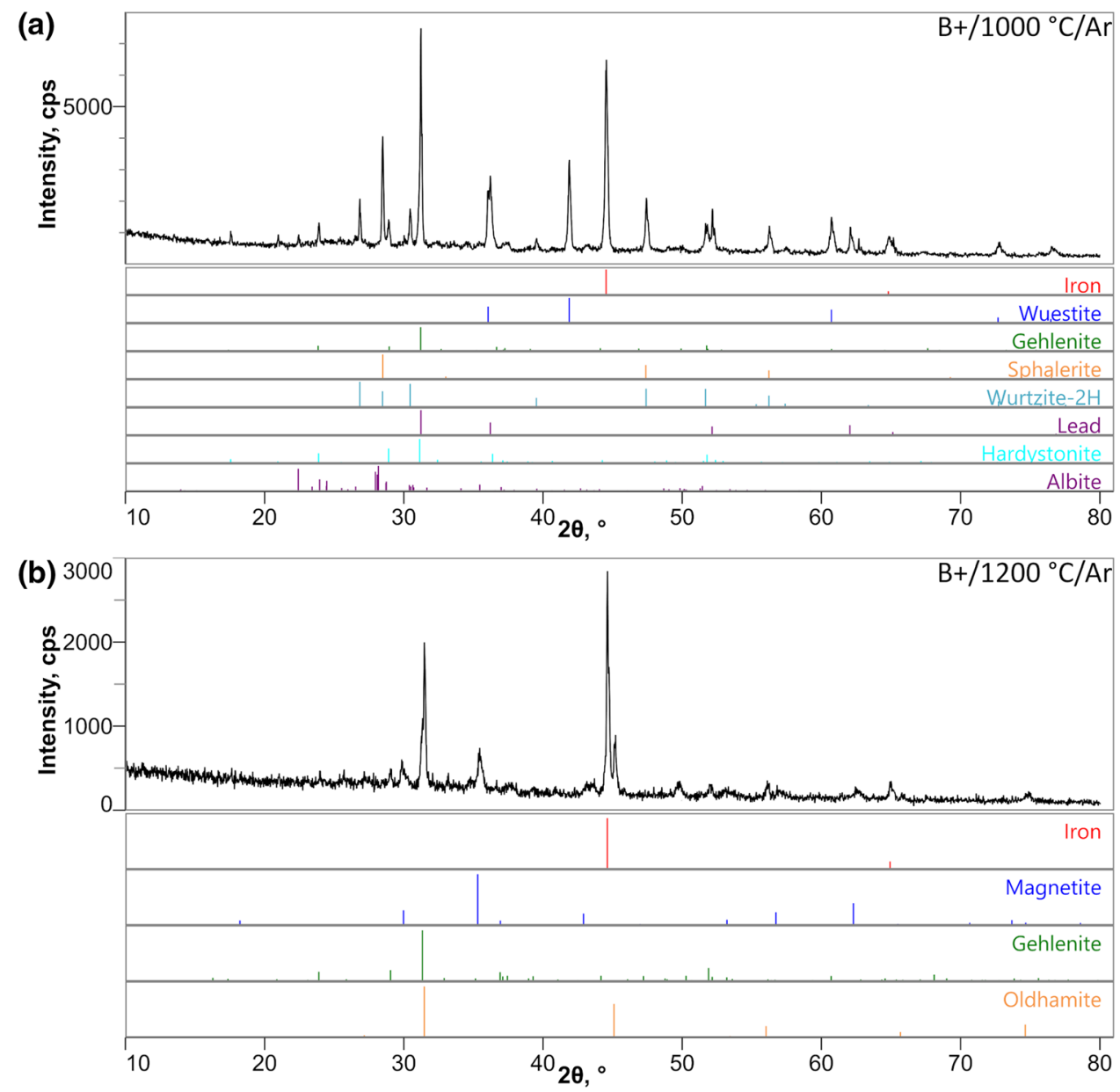

atmosphere $\left(\mathrm{CO} / \mathrm{N}_{2}=30 / 70 \%\right)$. The average $\mathrm{RDI}-2_{-2.8}$ index was $39 \%$. This value is lower than what was obtained by reducing iron ore sinter in the controlled $\mathrm{CO}-\mathrm{H}_{2}-\mathrm{N}_{2}-\mathrm{CO}_{2}$ $\mathrm{H}_{2} \mathrm{O}$ atmosphere [74] but higher than the threshold to ensure the smooth operation of blast furnaces charged with briquettes $(<30 \%)$. For values of this index greater than $35-40 \%$, the blast furnaces' performance was affected [67].

Swelling index, determined after an exposure at $900{ }^{\circ} \mathrm{C}$ for $60 \mathrm{~min}$ in a controlled atmosphere $\left(\mathrm{CO} / \mathrm{N}_{2}=30 / 70 \%\right)$ ranged from $-10 \%$ to $-12 \%$, meaning a contraction of volume due to the reduction of iron oxide to metallic iron, as is shown in Fig. 18a. Similar results were obtained by Singh and Bjorkman for cylindrical briquettes with low-sized particles $\left(d_{50}<74 \mu \mathrm{m}\right)[75]$, even if most of the literature records report an increase in volume after exposing briquettes to reducing environment [76, 77]. This is probably due to the low alkalinity of the mix $(\sim 0.5)$ that favors the shrinkage of the volume during the reduction from wustite to iron [78]. In addition, the briquettes retained almost the original shape, with an overall contraction both in height and diameter, even if high fraction of cracks are formed on the surface as also shown by Bagatini et al. [77]. The obtained results comply with the threshold of $20 \%$, which is considered acceptable according to the literature [70] for blast furnace operation.

Finally, the reducibility was evaluated by recording the mass loss over time by keeping the briquettes under a controlled atmosphere $\left(\mathrm{CO} / \mathrm{N}_{2}=40 / 60 \%\right)$ at $950{ }^{\circ} \mathrm{C}$ for $4 \mathrm{~h}$ (Fig. 18b). An overall mass loss of over $37 \%$ was achieved, in total agreement to TG-DSC analysis conducted on loose mix and as stated in the previous paragraph. The final degree of reduction was higher than $80 \%$, a result similar to the briquettes test by Kemppainen et al. [76].

Although the different tests (swelling, disintegration, reducibility) were performed in different conditions, for some of the briquettes, swelling index $\left(V_{\mathrm{FS}}\right)$ was still calculated. In Fig. 19, the evolution of $V_{\mathrm{FS}}$ as a function of temperature and degree of reduction (RD) was reported. Swelling formed similar to what was observed by Singh and Bjorkman [75] and Iljana et al. for acidic pellets [78], with a high-volume expansion at low temperature $\left(760^{\circ} \mathrm{C}\right)$ during the reduction of magnetite to wustite and then a shrinkage in the wustite to iron reduction step. This is confirmed by the trend of swelling as a function of the degree of reduction. At $760{ }^{\circ} \mathrm{C}$, the RD is slightly higher than $40 \%$, in total 


\section{Briq1}

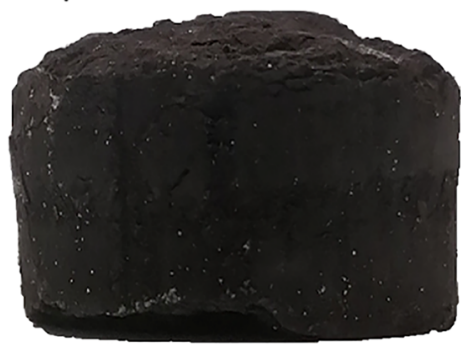

Briq2

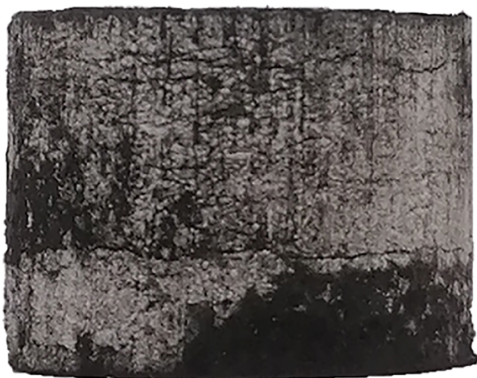

before reducing
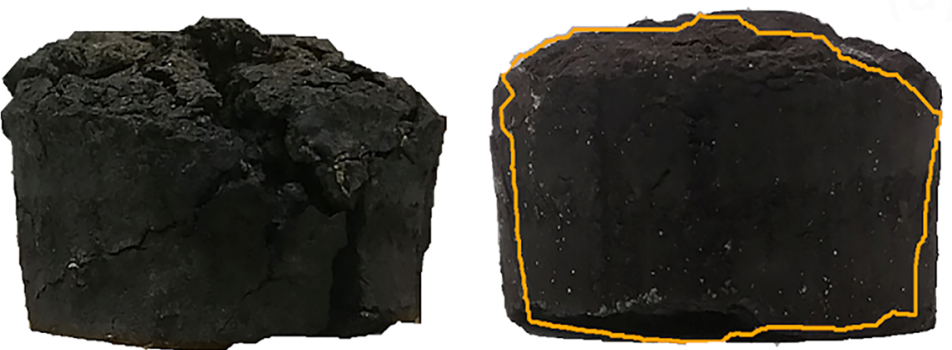

(a)

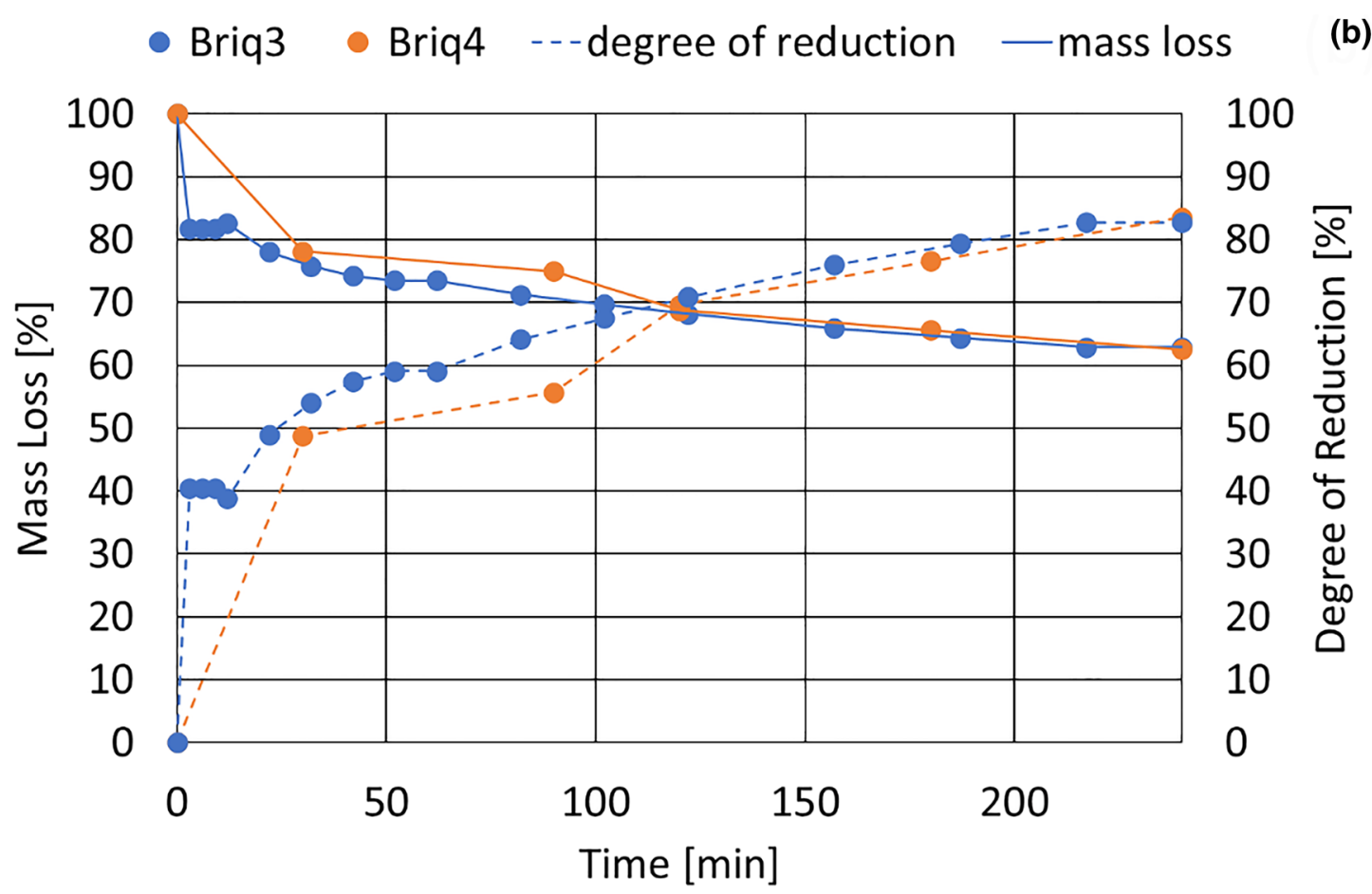

Fig. 18 a comparison of briquette before and after reduction at $900{ }^{\circ} \mathrm{C}$ for 60 min under controlled atmosphere $\left(\mathrm{CO} / \mathrm{N}_{2}=30 / 70 \%\right)$; b mass loss Vs time for reduced briquettes at $950{ }^{\circ} \mathrm{C}$ under controlled atmosphere $\left(\mathrm{CO} / \mathrm{N}_{2}=40 / 60 \%\right)$ for $4 \mathrm{~h}$

agreement with the experiments conducted by Iljana et al. [78], thus confirming that at that temperature, magnetite to wustite reduction occurs. Increasing the temperature, the RD increases proportionally while the briquettes start to shrink due to the formation of metallic iron and volatilization of $\mathrm{Zn}$ and $\mathrm{Pb}$ compounds. 


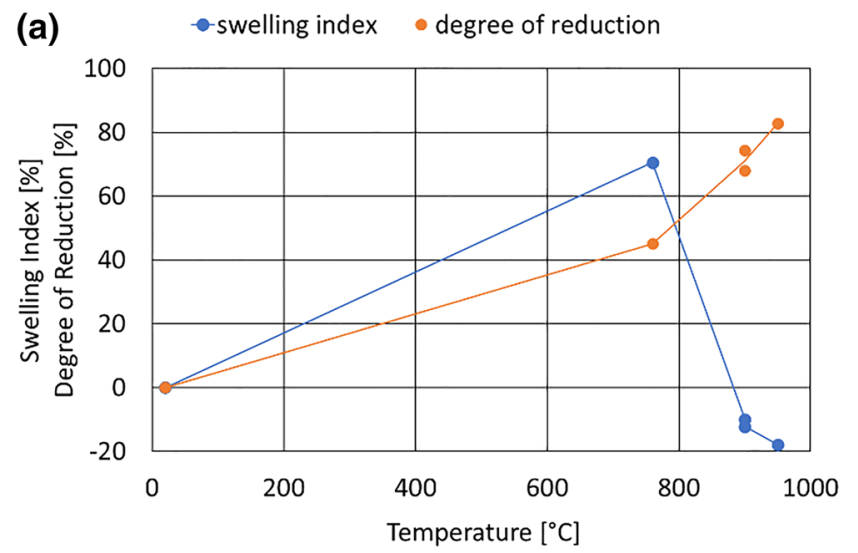

(b)

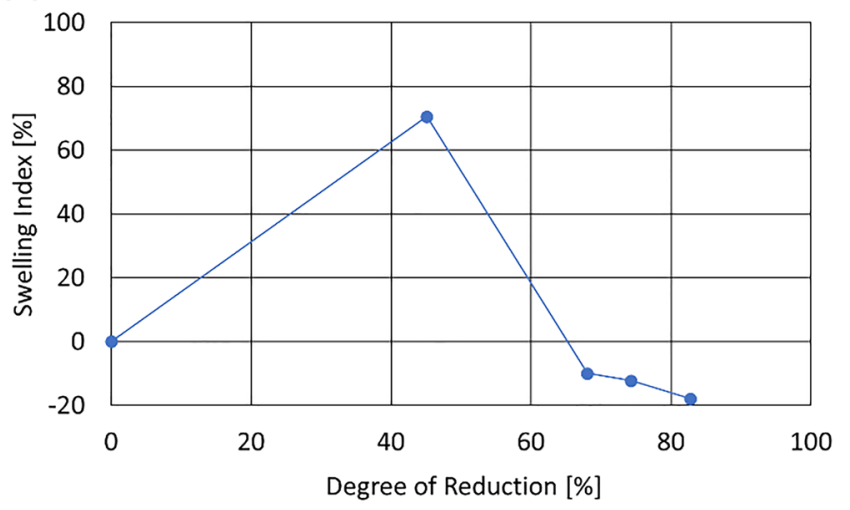

Fig. 19 Evolution of swelling index and degree of reduction as a function of temperature (a) and relationship between degree of reduction and swelling (b)

\section{Discussion}

The aim of this work being the production and characterization of self-reducing briquettes to be used in a thermal reactor, such as a Midrex or a cupola furnace, a comparison with the characteristics of the input materials of such reactors was made.

Midrex process is the world leader in direct reduction technology, and it is based on a shaft furnace feed by iron ores that are reduced by a reducing atmosphere in countercurrent made by a mixture of $\mathrm{CO}$ and $\mathrm{H}_{2}$. Maximum operating temperature is less than $1000^{\circ} \mathrm{C}$. Typical input feedstock of the shaft are pellets or lumps that should have at least $85 \%$ of tumbler resistance, a fine fraction below $6 \mathrm{wt} \%$ and a minimum compressive strength of $150 \mathrm{~kg}$ (roughly $15 \mathrm{MPa}$ if considering the lateral surface) [79]. Recently, extruded briquettes (brex) made of pellets fine, metallized sludge from DRI production, mill scale, and EAF dust were tested in a full-scale Midrex reactor. Even if such brex briquettes have a maximum compressive strength below $11 \mathrm{MPa}$, they behave well in the shaft [26]. Thus, from a mechanical point of view, the briquettes discussed in the current paper almost meet the requirement for acceptable Midrex input material, since they possess an average CCS of $12 \mathrm{MPa}$ when pressed at $40 \mathrm{MPa}$ and showed good tumbler resistance, always over $90 \%$ for well-briquetted material, and weak fines generation (less than 5\%). However, from a chemical point of view, the excess of $\mathrm{S}, \mathrm{Zn}$, and $\mathrm{Pb}$, do not encourage their use, mainly because the thermal level in the shaft will not be enough to reduce and completely volatilize $\mathrm{Zn}$ and $\mathrm{Pb}$, as observed in the heat-treated briquettes.

On the other hand, one of the advantages of cupolas is that they can easily process high amounts of zinc in the burden which may either originate from steel plant residuals or from automotive scrap. In addition, most of the iron is reduced at a wide temperature range $\left(900-1400{ }^{\circ} \mathrm{C}\right)$ over a short period of time, generally 20-30 min [25]. Being not reference values for input material in cupolas, a comparison was made with carbon-bearing briquettes physical properties. Typical anthracite- or biocarbon-based briquettes for coke replacement in cupola furnace possess a CCS in the range 2-14 MPa, high enough to keep their structure at a high temperature [24, 80, 81]. In addition, self-reducing briquettes made by several steelmaking waste were judged suitable for Cupola reduction if they possess a CCS $>5 \mathrm{MPa}$ [25].

Thus, the specific threshold for Midrex ${ }^{\circledR}$ neither cupolas being unavailable, a direct comparison of the obtained results for swelling and disintegration is not possible. However, the high-temperature properties of such briquettes seem to be suitable for their operation in blast furnace. Thus, it is reasonable to assume that, at least from the mechanical point of view, the briquettes are suitable both for Midrex ${ }^{\circledR}$ and cupola. For instance, the B+briquettes conserve enough strength to avoid high fine formation at high temperature, mainly due to the absence of swelling promoted by the low alkalinity of the mix.

On the other hand, from a chemical point of view, the higher temperatures developed in the cupolas can remove the harmful elements $(\mathrm{Zn}, \mathrm{Pb})$ opening a feasible possibility to use jarosite-blast furnace briquettes as input material in such a furnace. In addition, even the sulfur content of the produced cast iron might be high (5-6 wt \%) [23], a desulfurization process can be provided to refine the iron composition, both in the cupola or in a ladle [82].

Finally, for instance, the lower permissible compressive strength required to withstand the pressure of the overlying layers of $30 \mathrm{~m}$ blast furnace is 5.8-6.0 MPa. Being a cupola furnace generally the half in height of a blast furnace, it is auspicious that the proposed briquettes can withstand the pressure of burden inside the cupola. Hence, the proposed 
briquettes possess sufficient mechanical strength to be applied in industrial scale.

\section{Conclusions}

The briquetting of the jarosite sludges together with blast furnace sludges was successful with binder addition. Briquettes with no starch addition as a binder showed little absence of mechanical resistance, therefore their production is not preferable. A desirable control of the roasting process of the jarosite powder, previously to the briquetting, is needed so as to promote the decomposition of sodium sulfate into sodium oxide, to avoid the thenardite crystallization during the briquettes drying, which may dramatically hinder the briquettes' resistance.

A good control of the starch gelatinization is needed to provide the desired agglomerating forces.

The ultimate compressive strengths observed from the $\mathrm{B}+$ and $\mathrm{C}+$ briquettes, with average values higher than $12 \mathrm{MPa}$, tumbler index higher than $90 \%$ after 200 rotations, and an IRI higher than 500, provide sufficient high mechanical properties for the industrial application of the briquettes.

With respect only to the mechanical properties, the addition of $5 \mathrm{wt} \%$ of gelatinized starch seems to be the most reasonable choice; furthermore, the mechanical properties obtained using a briquetting pressure of $40 \mathrm{MPa}$ seem to be the best ones due to the fact that no significant influence has been observed from the binder amount to the final properties of the briquettes.

Finally, the physical, mechanical, and metallurgical properties developed during agglomeration allow the use of such briquettes as feedstock for cupola furnace.

Acknowledgements The authors would like to acknowledge Rives S.r.l. (Cinisello Balsamo (MI), Italy) for supplying the spring, ejectors, and mold used for briquetting machine setup. The authors would also like to thank Ing. Gianluca Dall'Osto for helping in high-temperature characterization tests.

Author Contributions DM: conceptualization, methodology, visualization, and writing — original draft; DLG: formal analysis, investigation, data curation, and writing - original draft; CM: supervision, writingreview and editing; SB: validation, writing—review and editing; AG: resources.

Funding Open access funding provided by Politecnico di Milano within the CRUI-CARE Agreement. The present research was also supported by the Italian Ministry for Education, University and Research (MIUR) through the project "Department of Excellence LIS4.0" (Integrated Laboratory for Lightweight and Smart Structures).

\section{Declarations}

Conflict of interest On behalf of all authors, the corresponding author states that there is no conflict of interest.
Open Access This article is licensed under a Creative Commons Attribution 4.0 International License, which permits use, sharing, adaptation, distribution and reproduction in any medium or format, as long as you give appropriate credit to the original author(s) and the source, provide a link to the Creative Commons licence, and indicate if changes were made. The images or other third party material in this article are included in the article's Creative Commons licence, unless indicated otherwise in a credit line to the material. If material is not included in the article's Creative Commons licence and your intended use is not permitted by statutory regulation or exceeds the permitted use, you will need to obtain permission directly from the copyright holder. To view a copy of this licence, visit http://creativecommons.org/licenses/by/4.0/.

\section{References}

1. Jha MK, Kumar V, Singh RJ (2001) Review of hydrometallurgical recovery of zinc from industrial wastes. Resour Conserv Recycl 33:1-22. https://doi.org/10.1016/S0921-3449(00)00095-1

2. Grant RM (2001) Zinc Production. Encycl Mater Sci Technol. https://doi.org/10.1016/b0-08-043152-6/01790-3

3. Gwyther D (2004) Impact of the deposition of jarosite on deepwater meiobenthos in southeastern Australia. Mar Pollut Bull 48:992-997. https://doi.org/10.1016/j.marpolbul.2004.02.021

4. Min XB, Xie X De, Chai LY, et al (2013) Environmental availability and ecological risk assessment of heavy metals in zinc leaching residue. Trans Nonferrous Met Soc China (English Ed 23:208-218. https://doi.org/10.1016/S1003-6326(13)62448-6

5. Kerolli-Mustafa M, Ćurković L, Fajković H, Rončević S (2015) Ecological risk assessment of jarosite waste disposal. Croat Chem Acta 88:189-196. https://doi.org/10.5562/cca2554

6. Kerolli-Mustafa M, Ćurković L (2016) Analysing the characteristics and application potentials of jarosite waste in Kosovo. Glob Nest J 18:89-97. https://doi.org/10.30955/gnj.001799

7. Seyer S, Chen TT, Dutrizac JE (2001) Jarofix: Addressing iron disposal in the zinc industry. JOM 53:32-35. https://doi.org/10. 1007/s11837-001-0010-2

8. Mymrin VA, Ponte HA, Impinnisi PR (2005) Potential application of acid jarosite wastes as the main component of construction materials. Constr Build Mater. https://doi.org/10.1016/j.conbuildmat.2004.05.009

9. Katsioti M, Boura P, Agatzini S et al (2005) Use of jarosite/alunite precipitate as a substitute for gypsum in Portland cement. Cem Concr Compos 27:3-9. https://doi.org/10.1016/j.cemconcomp. 2003.10.002

10. Palden T, Regadío M, Onghena B, Binnemans K (2019) Selective metal recovery from jarosite residue by leaching with acidequilibrated ionic liquids and precipitation-stripping. ACS Sustain Chem Eng 7:4239-4246. https://doi.org/10.1021/acssuschemeng. 8b05938

11. Noranda Income Fund Environmental, and Occupational Health and Safety. http://www.norandaincomefund.com/corporate/envir onment.html. Accessed 12 May 2021

12. Beena KS, Santhosh G (2021) Transport geotechnical properties of lateritic soil stabilized with Jarofix and lime. Environ Dev Sustain 23:1601-1622. https://doi.org/10.1007/ s10668-020-00641-0

13. Zhu D, Yang C, Pan J et al (2018) New pyrometallurgical route for separation and recovery of $\mathrm{Fe}, \mathrm{Zn}, \mathrm{In}, \mathrm{Ga}$ and $\mathrm{S}$ from jarosite residues. J Clean Prod 205:781-788. https://doi.org/10.1016/j. jclepro.2018.09.152

14. Mombelli D, Mapelli C, Di Cecca C et al (2018) Characterization of cast iron and slag produced by jarosite sludges reduction via Arc Transferred Plasma (ATP) reactor. J Environ Chem Eng 6:773-783. https://doi.org/10.1016/j.jece.2018.01.006 
15. Saikia J, Saikia P, Boruah R, Saikia BK (2015) Ambient air quality and emission characteristics in and around a non-recovery type coke oven using high sulphur coal. Sci Total Environ 530531:304-313. https://doi.org/10.1016/j.scitotenv.2015.05.109

16. Huo H, Lei Y, Zhang Q et al (2012) China's coke industry: Recent policies, technology shift, and implication for energy and the environment. Energy Policy 51:397-404. https://doi.org/10.1016/j. enpol.2012.08.041

17. Jan B, Pieter van der M, J.M. S, et al (2019) EMEP/EEA air pollutant emission inventory guidebook 2019

18. Zhang Y, Tao S, Shen H, Jianmin M (2009) Inhalation exposure to ambient polycyclic aromatic hydrocarbons and lung cancer risk of Chinese population. Proc Natl Acad Sci USA 106:21063-21067. https://doi.org/10.1073/pnas.0905756106

19. Pustejovská P, Brožová S, Jursová S (2010) Environmental benefits of coke consumption decrease. In: METAL 2010 - 19th International Conference on Metallurgy and Materials, Conference Proceedings, pp 79-83

20. Mombelli D, Barella S, Gruttadauria A, Mapelli C (2019) Iron recovery from bauxite tailings red mud by thermal reduction with blast furnace sludge. Appl Sci. https://doi.org/10.3390/app92 24902

21. Mombelli D, Di Cecca C, Mapelli C et al (2016) Experimental analysis on the use of BF-sludge for the reduction of BOF-powders to direct reduced iron (DRI) production. Process Saf Environ Prot 102:410-420. https://doi.org/10.1016/j.psep.2016.04.017

22. Rath SS, Rao DS, Tripathy SK, Biswal SK (2018) Characterization vis-á-vis utilization of blast furnace flue dust in the roast reduction of banded iron ore. Process Saf Environ Prot 117:232 244. https://doi.org/10.1016/j.psep.2018.05.007

23. Mombelli D, Mapelli C, Barella S et al (2019) Jarosite wastes reduction through blast furnace sludges for cast iron production. J Environ Chem Eng. https://doi.org/10.1016/j.jece.2019.102966

24. Nieto-Delgado C, Cannon FS, Paulsen PD et al (2014) Bindered anthracite briquettes as fuel alternative to metallurgical coke: Full scale performance in cupola furnaces. Fuel 121:39-47. https://doi. org/10.1016/j.fuel.2013.12.034

25. Holtzer M, Kmita A, Roczniak A (2015) The recycling of materials containing iron and zinc in the OxyCup process. Arch Foundry Eng 15:126-130

26. Bizhanov A, Malysheva T (2017) Metallization of extruded briquettes (BREX) in Midrex process. Metals (Basel) 7:259. https:// doi.org/10.3390/met7070259

27. Young B (2015) Using binders to briquette carbonaceous materials and steel wastes

28. Borowski G, Stępniewski W, Wójcik-oliveira K (2017) Effect of starch binder on charcoal briquette properties. Int Agrophys. https://doi.org/10.1515/intag-2016-0077

29. Smith GO (1908) Binders For Coal Briquettes. Department of the Interior, United States Geological Survey, Bulletin 343

30. Drobíková K, Vallová S, Motyka O et al (2018) Effects of binder choice in converter and blast furnace sludge briquette preparation: environmental and practical implications. Waste Manag 79:30-37. https://doi.org/10.1016/j.wasman.2018.06.051

31. Sivrikaya O, Arol AI (2014) Alternative binders to bentonite for iron ore pelletization. Holos 3:94-103

32. Kumar DS, Sah R, Sekhar VR, Vishwanath SC (2017) Development and use of mill scale briquettes in BOF. Ironmak Steelmak 44:134-139. https://doi.org/10.1080/03019233.2016.1165499

33. Li Y, Han Y, Sun Y et al (2018) Growth behavior and size characterization of metallic iron particles in coal-based reduction of oolitic hematite-coal composite briquettes. Minerals. https://doi. org/10.3390/min 8050177

34. Omran M, Fabritius T, Paananen T (2017) Effect of blast furnace sludge (BFS) characteristics on suitable recycling process determining. J Miner Mater Charact Eng 05:185-197. https://doi. org/10.4236/jmmce.2017.54016

35. Mansfeldt T, Dohrmann R (2004) Chemical and mineralogical characterization of blast-furnace sludge from an abandoned landfill. Environ Sci Technol 38:5977-5984

36. El-hussiny NA, Khalifa AA, El-midany AA, et al (2015) Effect of replacement coke breeze by charcoal on technical operation of iron ore sintering. IJSER 6:681-686

37. Lian X, Cheng K, Wang D et al (2018) Analysis of crystals of retrograded starch with sharp X-ray diffraction peaks made by recrystallization of amylose and amylopectin. Int J Food Prop 20:S3224-S3236. https://doi.org/10.1080/10942912.2017.13624 33

38. Altayan MM, Ayaso M, Al Darouich T, Karabet F (2020) The effect of increasing soaking time on the properties of premixing starch-glycerol-water suspension before melt-blending process: comparative study on the behavior of wheat and corn starches. Polym Bull 77:1695-1706. https://doi.org/10.1007/ s00289-019-02826-8

39. Zasyonu JiNİ (2010) Gelatinization of waxy, normal and high amylose corn starches (in English). Gida 35:237-244

40. Blesa MJ, Miranda JL, Izquierdo MT, Moliner R (2003) Curing time effect on mechanical strength of smokeless fuel briquettes. Fuel Process Technol 80:155-167. https://doi.org/10.1016/S03783820(02)00243-6

41. Sen R, Wiwatpanyaporn S, Annachhatre AP (2016) Influence of binders on physical properties of fuel briquettes produced from cassava rhizome waste. Int J Environ Waste Manag 17:158-175. https://doi.org/10.1504/IJEWM.2016.076750

42. Narita CY, Mourao MB, Takano C et al (2015) Development of composite briquettes of iron ore and coal hardened by heat treatment. Ironmak Steelmak. https://doi.org/10.1179/1743281214Y. 0000000260

43. Hersey JA, Rees JE (1971) Deformation of particles during briquetting. Nat Phys Sci 230:96-96. https://doi.org/10.1038/physc i230096a0

44. Miles MJ, Morris VJ, Orford PD, Ring SG (1985) The roles of amylose and amylopectin in the gelation and retrogradation of starch. Carbohydr Res. https://doi.org/10.1016/S0008-6215(00) 90778-X

45. Pei-ling L, Xiao-song H, Qun S (2010) Effect of high hydrostatic pressure on starches: a review. 615-628. https://doi.org/10.1002/ star.201000001

46. Ackson DASJ (2006) Gelatinization and solubility of corn starch during heating in excess water: new insights. https://doi.org/10. 1021/jf0529114

47. Ebert WL, Rosine SD, Bakel AJ (1997) Gas evoution during vitrification of sodium sulfate and silica. Argonne

48. Blaser HD, Scherer OJ (1969) Expansion of soils containing sodium sulfate caused by drop in ambient temperatures. In: International Conference Effects of temperatures and heat on engineering behavior of soils. Highway Research Board, Washington (DC), pp 150-160

49. Rodriguez-Navarro C, Doehne E, Sebastian E (2000) How does sodium sulfate crystallize? Implications for the decay and testing of building materials. Cem Concr Res 30:1527-1534. https://doi. org/10.1016/S0008-8846(00)00381-1

50. Saidov TA, Pel L, Kopinga K (2015) Crystallization pressure of sodium sulfate heptahydrate. Cryst Growth Des 15:2087-2093. https://doi.org/10.1021/cg501537h

51. Fahey BD (1986) A comparative laboratory study of salt crystallisation and salt hydration as potential weathering agents in deserts. Geogr Ann Ser A 68:107-111. https://doi.org/10.1080/04353676. 1986.11880163

52. Sperling CHB, Cooke RU (1985) Laboratory simulation of rock weathering by salt crystallization and hydration processes in hot, 
arid environments. Earth Surf Process Landforms 10:541-555. https://doi.org/10.1002/esp.3290100603

53. Pietsch W (2001) Agglomeration processes. Wiley-VCH Verlag

54. Klimchouk A (1996) The dissolution and conversion of gypsum and anhydrite. Int J Speleol 25:21-36. https://doi.org/10.5038/ 1827-806x.25.3.2

55. Farnsworth M (1925) The hydration of anhydrite. Ind Eng Chem 17:967-970. https://doi.org/10.1021/ie50189a037

56. Scheinost AC (2004) Metal oxides. Encycl Soils Environ 4:428438. https://doi.org/10.1016/B0-12-348530-4/00194-6

57. Jang JH, Dempsey BA, Burgos WD (2007) Solubility of hematite revisited: effects of hydration. Environ Sci Technol 41:7303-7308. https://doi.org/10.1021/es070535t

58. Copeland L, Blazek J, Salman H, Tang MC (2009) Form and functionality of starch. Food Hydrocoll. https://doi.org/10.1016/j. foodhyd.2008.09.016

59. Wang S, Li C, Copeland L et al (2015) Starch retrogradation: a comprehensive review. Compr Rev Food Sci Food Saf 14:568585. https://doi.org/10.1111/1541-4337.12143

60. Han H, Duan D, Yuan P (2014) Binders and bonding mechanism for RHF briquette made from blast furnace dust. ISIJ Int 54:1781-1789. https://doi.org/10.2355/isijinternational.54.1781

61. Lemos LR, da Rocha SHFS, de Castro LFA et al (2019) Mechanical strength of briquettes for use in blast furnaces. Rev Esc Minas 72:63-69. https://doi.org/10.1590/0370-44672017720156

62. Mohamed FM, El-gawad HHA, Shalabi MEH (2018) Reduction of Egyptian El-Baharia iron Ore briquettes with bentonite as binding material by Hydrogen gas in static bed. IJSER 9:441-448

63. Mangena SJ, du Cann VM (2007) Binderless briquetting of some selected South African prime coking, blend coking and weathered bituminous coals and the effect of coal properties on binderless briquetting. Int J Coal Geol. https://doi.org/10.1016/j.coal.2006. 11.001

64. Teixeira SR, Pena AFV, Miguel AG (2010) Briquetting of charcoal from sugar-cane bagasse fly ash (scbfa) as an alternative fuel. Waste Manag 30:804-807. https://doi.org/10.1016/j.wasman. 2010.01.018

65. Rubio B, Izquierdo MT, Segura E (1999) Effect of binder addition on the mechanical and physicochemical properties of low rank coal char briquettes. Carbon N Y 37:1833-1841. https://doi.org/ 10.1016/S0008-6223(99)00057-3

66. El-Hussiny NA, Shalabi MEH (2011) A self-reduced intermediate product from iron and steel plants waste materials using a briquetting process. Powder Technol 205:217-223. https://doi.org/ 10.1016/j.powtec.2010.09.017

67. Lemos LR, Da Rocha SHFS, De Castro LFA (2015) Reduction disintegration mechanism of cold briquettes from blast furnace dust and sludge. J Mater Res Technol 4:278-282. https://doi.org/ 10.1016/j.jmrt.2014.12.002

68. Solodov V, Cherkasova T, Kolmakov N, et al (2019) Research of characteristics of PJSC "koks" coal and coke dust fuel briquettes.
E3S Web Conf 134:0-6. https://doi.org/10.1051/e3sconf/20191 3402007

69. Wu S, Chang F, Zhang J, et al (2017) Cold strength and high temperature behaviors of self-reducing briquette containing electric arc furnace dust and anthracite. ISIJ Int 57:1364-1373. https:// doi.org/10.2355/isijinternational.ISIJINT-2017-013

70. Takano C, Nascimento RC, e Silva GF, dos Santos DM, Mourão MB, Capocchi JD (2001) Recycling of solid wastes from integrated steelmaking plant: a sustainable alternative. Mater Trans 42(12):2506-10

71. Małecki S (2014) Thermogravimetric study of the reduction of basic lead sulphate. J Therm Anal Calorim 117:1091-1095

72. Zheng Y, Liu W, Qin W et al (2015) Reduction of lead sulfate to lead sulfide with carbon monoxide. J Cent South Univ 22:29292935. https://doi.org/10.1007/s11771-015-2828-8

73. Palandri JL, Rosenbauer RJ, Kharaka YK (2005) Ferric iron in sediments as a novel $\mathrm{CO} 2$ mineral trap: $\mathrm{CO} 2-\mathrm{SO} 2$ reaction with hematite. Appl Geochem 20:2038-2048. https://doi.org/10.1016/j. apgeochem.2005.06.005

74. Murakami T, Kamiya Y, Kodaira T, Kasai E (2012) Reduction disintegration behavior of iron ore sinter under high $\mathrm{H} 2$ and $\mathrm{H} 2 \mathrm{O}$ conditions. ISIJ Int 52:1447-1453. https://doi.org/10.2355/isiji nternational.52.1447

75. Singh M, Björkman B (2004) Effect of reduction conditions on the swelling behaviour of cement-bonded briquettes. ISIJ Int 44:294-303. https://doi.org/10.2355/isijinternational.44.294

76. Kemppainen A, Iljana M, Heikkinen EP et al (2014) Reduction behavior of cold-bonded briquettes under simulated blast furnace conditions. ISIJ Int 54:1539-1545. https://doi.org/10.2355/isiji nternational.54.1539

77. Bagatini MC, Fernandes T, Silva R et al (2020) Mill scale and flue dust briquettes as alternative burden to low height blast furnaces. J Clean Prod 276:124332. https://doi.org/10.1016/j.jclepro.2020. 124332

78. Iljana M, Mattila O, Alatarvas T et al (2012) Dynamic and isothermal reduction swelling behaviour of olivine and acid iron ore pellets under simulated blast furnace shaft conditions. ISIJ Int 52:1257-1265. https://doi.org/10.2355/isijinternational.52.1257

79. Chevrier V (2019) Direct from MIDREX - 4th quarter 2019. Charlotte

80. Mousa E, Kazemi M, Larsson M et al (2019) Potential for developing biocarbon briquettes for foundry industry. Appl Sci 9:5288. https://doi.org/10.3390/app9245288

81. Noh YD, Komarneni S, Cannon FS et al (2016) Anthracite briquettes with plant byproducts as an ecofriendly fuel for foundries. Fuel 175:210-216. https://doi.org/10.1016/j.fuel.2016.02.049

82. Carter JSF (1953) Cupola melting of cast iron. U.S. Patent $2,643,185$

Publisher's Note Springer Nature remains neutral with regard to jurisdictional claims in published maps and institutional affiliations.

\section{Authors and Affiliations}

\section{Davide Mombelli ${ }^{1}$ (1) . Danilo Luvizotto Gonçalves ${ }^{1} \cdot$ Carlo Mapelli $^{1} \cdot$ Silvia Barella ${ }^{1} \cdot$ Andrea Gruttadauria $^{1}$}

Davide Mombelli

davide.mombelli@polimi.it
1 Dipartimento di Meccanica, Politecnico di Milano, Via La Masa 1, 20156 Milano, Italy 